February 2000 - NREL/TP-710-25266

\title{
U.S. Guidelines for the Economic Analysis of Building-Integrated Photovoltaic Power Systems
}

\author{
Patrina Eiffert, Ph.D. \\ Arlene Thompson
}

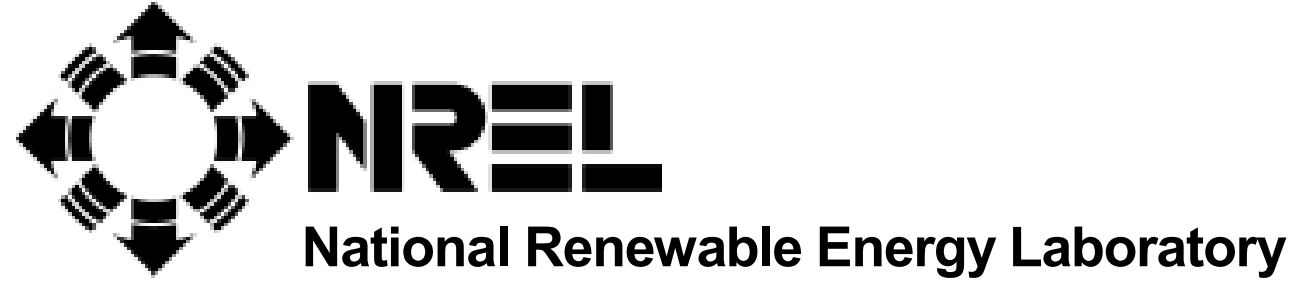

1617 Cole Boulevard Golden, Colorado 80401-3393

NREL is a U.S. Department of Energy Laboratory Operated by Midwest Research Institute $\bullet$ Battelle $\bullet$ Bechtel 


\section{U.S. Guidelines for the Economic Analysis of Building-Integrated Photovoltaic Power Systems}

Patrina Eiffert, Ph.D.

Arlene Thompson

Prepared under Task No. PV00.8201

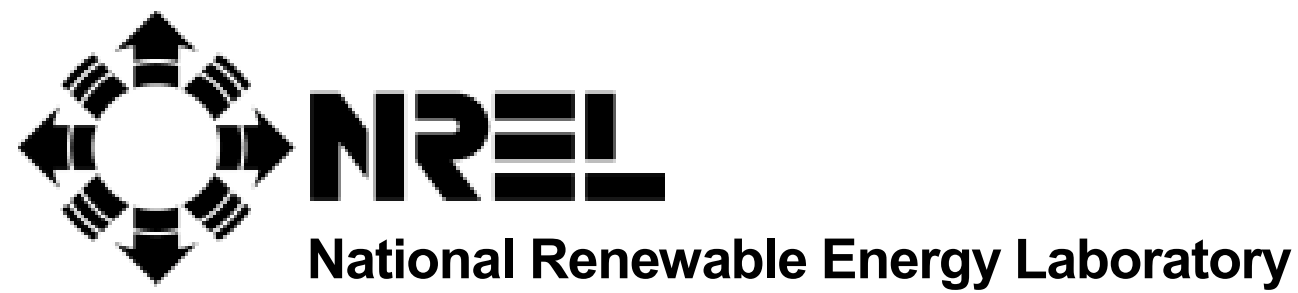

1617 Cole Boulevard

Golden, Colorado 80401-3393

NREL is a U.S. Department of Energy Laboratory

Operated by Midwest Research Institute $\bullet$ Battelle $\bullet$ Bechtel

Contract No. DE-AC36-99-G010337 


\section{NOTICE}

This report was prepared as an account of work sponsored by an agency of the United States government. Neither the United States government nor any agency thereof, nor any of their employees, makes any warranty, express or implied, or assumes any legal liability or responsibility for the accuracy, completeness, or usefulness of any information, apparatus, product, or process disclosed, or represents that its use would not infringe privately owned rights. Reference herein to any specific commercial product, process, or service by trade name, trademark, manufacturer, or otherwise does not necessarily constitute or imply its endorsement, recommendation, or favoring by the United States government or any agency thereof. The views and opinions of authors expressed herein do not necessarily state or reflect those of the United States government or any agency thereof.

Available electronically at http://www.doe.gov/bridge

Available for a processing fee to U.S. Department of Energy

and its contractors, in paper, from:

U.S. Department of Energy

Office of Scientific and Technical Information

P.O. Box 62

Oak Ridge, TN 37831-0062

phone: 865.576.8401

fax: 865.576.5728

email: reports@adonis.osti.gov

Available for sale to the public, in paper, from:

U.S. Department of Commerce

National Technical Information Service

5285 Port Royal Road

Springfield, VA 22161

phone: 800.553.6847

fax: 703.605.6900

email: orders@ntis.fedworld.gov

online ordering: http://www.ntis.gov/ordering.htm

Printed on paper containing at least $50 \%$ wastepaper, including $20 \%$ postconsumer waste. 


\section{Acknowledgments}

Funding for this project was provided by Photovoltaics for Buildings within the National Center for Photovoltaics (NCPV) at the National Renewable Energy Laboratory. Support for the NCPV is provided by the United States Department of Energy (DOE) Office of Power Technologies. The project was also funded by DOE's Federal Energy Management Program.

Much of this work is based on guiding principles already established by the National Institute for Standards and Technology (NIST) within the U.S. Department of Commerce's Office of Applied Economics. NIST pioneered the development of building life-cycle cost analysis relative to energy usage and conservation in buildings. The authors wish to acknowledge the valuable contributions of Rosalie Ruegg from NIST. 


\section{Glossary}

After-tax analysis - Economic assessments that take tax effects into account.

Balance of system (BOS) - BOS is a term used to refer to those components other than photovoltaic modules. BOS includes the power conditioning equipment (inverter and rectifier), array foundation, support structure, sun-trackers (optional), backup power (usually a battery bank), wiring, and electrical system protection devices.

Break-even analysis - A technique for dealing with uncertainty in cost and benefit estimates; entails determining the minimum or maximum value that a variable can have and still result in a project whose present value benefits (savings) will just cover its costs. (Note: The time to pay back is a measure of break-even life.)

Energy savings performance contracting (ESPC) - Authorized by the Energy Policy Act of 1992 (EPAct), the ESPC option allows energy service companies to assume the capital costs of installing energy and water conservation equipment and renewable energy systems. In the ESPC process, the energy service company guarantees a fixed amount of energy cost savings throughout the life of the contract (up to 25 years) and is paid directly from those cost savings. Agencies retain the remainder of the energy cost savings for themselves. ("Energy cost savings" refers to any reduction in utilities for a federal building.)

First-cost approach-Selecting among alternatives based on which has the lowest upfront costs.

Life-cycle cost (LCC) - The sum of time-equivalent costs of acquiring, owning, operating, and maintaining a building, system, or equipment over a designated study period. Comparing LCCs of alternative building designs, systems, or equipment that equally satisfy functional requirements is one way of choosing among them based on economic grounds.

Low-E (low-emittance) coating or glazing-Microscopically thin and virtually invisible metal or metallic oxide layers deposited on a window or skylight glazing surface, primarily to reduce the U-value by suppressing radiative heat flow. A typical type of low-E coating is transparent to the solar spectrum (visible light and short-wave infrared radiation) and reflective of long-wave infrared radiation.

Marginal (or added) cost - The difference between the total building system cost with and without the added photovoltaic system.

Marginal cost of capital-The rate of return on the next-best available use of investment funds. An investor typically uses this rate to establish the discount rate and the minimum acceptable rate of return. 
Minimum acceptable rate of return - The minimum percentage return required for an investment to be economically acceptable.

Net benefit analysis - The net difference between two (energy) systems, taking into account the relative benefits and costs, expressed in present or annual value dollars.

Payback period-The minimum time it takes to recover an investment. The "simple payback period" for an energy system is the total investment cost divided by the first year's revenues from energy saved, displaced, or produced.

Savings-to-investment (or benefit-to-cost) ratio-A ratio of savings to costs, or benefits to costs, for one building design, system, equipment, or strategy versus an alternative.

Time value of money - The time-dependent value of money arising from price inflation/deflation and from its real earning potential over time. 


\section{Acronyms and Abbreviations}

$\begin{array}{ll}\text { AIRR } & \text { adjusted internal rate of return } \\ \text { BIPV } & \text { building-integrated photovoltaic } \\ \text { BLCC } & \text { Building Life-Cycle Costs (computer program) } \\ \text { BLM } & \text { Bureau of Land Management } \\ \text { BOS } & \text { balance of system } \\ \mathrm{CO}_{2} & \text { carbon dioxide } \\ \text { DOE } & \text { U.S. Department of Energy } \\ \text { DOI } & \text { U.S. Department of Interior } \\ \text { DSIRE } & \text { National Database of State Incentives for Renewable Energy } \\ \text { EREC } & \text { Efficiency and Renewable Energy Clearing House } \\ \text { FEMP } & \text { Federal Energy Management Program } \\ \text { GDS } & \text { Governmental Data Services } \\ \text { IPMVP } & \text { International Performance Measurement and Verification Protocol } \\ \text { IREC } & \text { Interstate Renewable Energy Council } \\ \text { kW } & \text { kilowatt } \\ \text { kWh } & \text { kilowatt-hour } \\ \text { LCC } & \text { life-cycle cost } \\ \text { M\&V } & \text { measurement and verification } \\ \text { MARR } & \text { minimum acceptable rate of return } \\ \text { NCPV } & \text { National Center for Photovoltaics } \\ \text { NIST } & \text { National Institute for Standards and Technology } \\ \text { NOX } & \text { nitrous oxide } \\ \text { NPS } & \text { National Park Service } \\ \text { NPV } & \text { net present value } \\ \text { NREL } & \text { National Renewable Energy Laboratory } \\ \text { O\&M } & \text { operations and maintenance } \\ \text { OSHA } & \text { Occupational Safety and Health Administration } \\ \text { PUCs } & \text { public utility commissions } \\ \text { PV } & \text { photovoltaic } \\ \text { PV:BONUS } & \text { Photovoltaics: Building Opportunities in the United States } \\ \text { PVI } & \text { present value of investment costs } \\ \text { RWG } & \text { Renewable Working Group } \\ \text { SBA } & \text { Small Business Administration } \\ \text { SIR } & \text { savings-to-investment ratio } \\ \text { SO } & \text { sulfur dioxide } \\ \text { TMY } & \text { typical meteorological year } \\ \text { TV } & \text { terminal value } \\ \text { UPS } & \text { uninterruptible power supply } \\ \text { UPVG } & \text { Utility PhotoVoltaic Group } \\ & \end{array}$




\section{Executive Summary}

Traditionally, electrical service for buildings has been provided by one predetermined supplier - the utility company. An unexpected side effect of the privatization and deregulation of the electricity industry, initiated during the late 1980s and early 1990 s, is the opportunity for consumers to purchase electricity from a variety of energy service companies or to generate electricity themselves. Concurrently, the U.S. Department of Energy, national energy laboratories, universities, and photovoltaic (PV) manufacturers have technically evaluated, tested, and demonstrated building-integrated photovoltaics (BIPV) to be a viable technology.

Electricity industry restructuring and successful PV research and development raise a dilemma for building owners: is it worth the investment and effort to engage in the process of generating electricity with photovoltaics for individual buildings?

A BIPV power system operates as a multifunctional building construction material; it generates energy as well as serves as part of the building envelope. The objective of the U.S. Guidelines for the Economic Assessment of Building-Integrated Photovoltaic Power Systems is to identify the economic parameters of BIPV systems. Identifying these parameters will enable the decision-makers to appraise the economic feasibility and implications of investments in such building systems.

Section 1 identifies general methods of assessing the economic performance of BIPV power systems. A major barrier to analyzing renewable energy systems is assembling and presenting the technical and financial data in forms that will help a client determine if a BIPV power system would make economic sense. Economic methods of investment analysis, including payback period, net benefit analysis, savings-toinvestment ratio, adjusted internal rate of return, and life-cycle cost analysis, are presented for use by the owner-occupant, owner-investor, and owner-developer.

Section 2 describes the benefits of BIPV systems, which can affect the decisionmaking process. These benefits derive from such factors as energy cost savings, revenue or credits from the sale of power, enhanced power quality and reliability, reduced construction costs, reductions in environmental emissions, increased rents, tax credits, rebates, and other incentives. Some of these benefits can be identified, evaluated in monetary terms, and entered into the calculation of economic performance. Other effects may be difficult to quantify and are considered qualitatively.

Section 3 characterizes the relative costs of BIPV power systems for the building owner. Limited published data is available on BIPV power system costs. A preliminary survey conducted in this study indicates that manufacturer marketing representatives provide widely varying cost estimates. Consequently, a variety of vendor bids should be gathered and reviewed prior to making an investment decision. There can also be hidden or unexpected costs, which will be examined in this section.

Section 4 specifies measurement and verification (M\&V) for BIPV power systems. Prescribing an internationally accepted guideline for $M \& V$ can ensure that generation and savings requirements in BIPV power systems will be accurately, consistently, and objectively determined. 


\section{Contents}

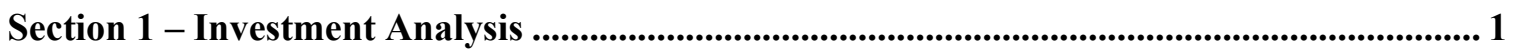

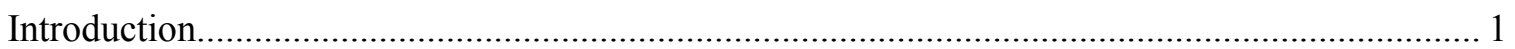

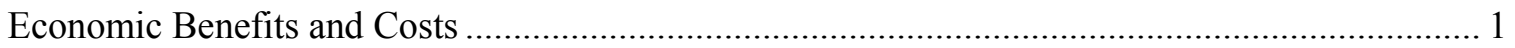

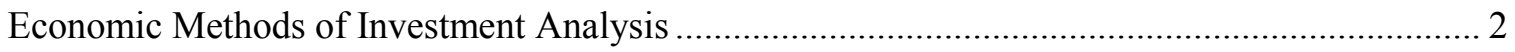

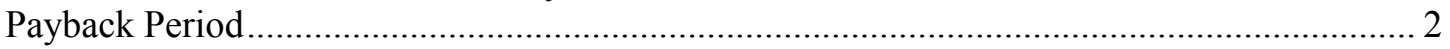

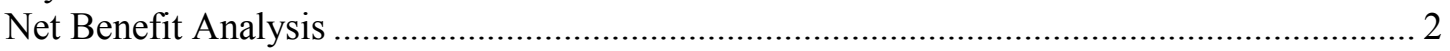

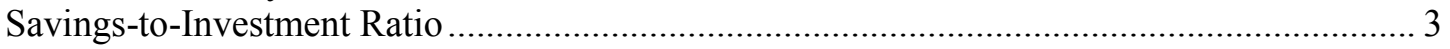

Adjusted Internal Rate of Return ................................................................................ 3

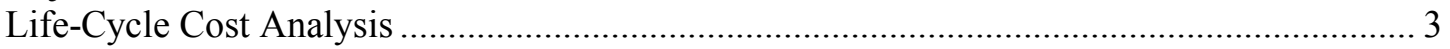

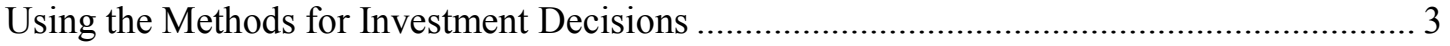

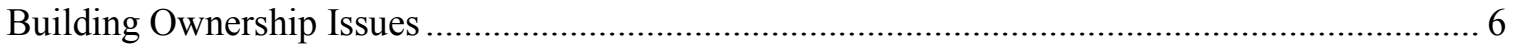

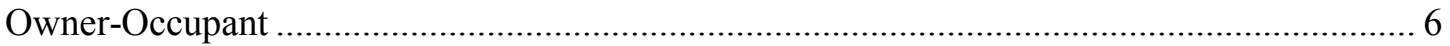

Owner-Investor . .

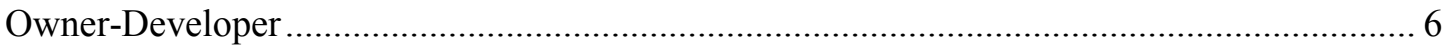

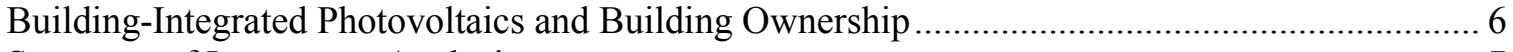

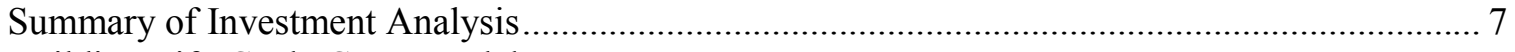

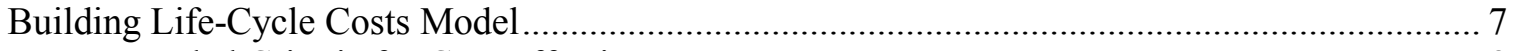

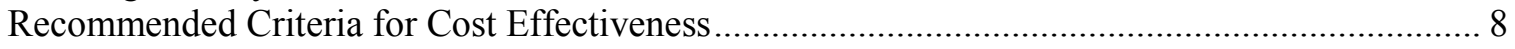

Section 2 - Benefits of BIPV Power Systems...................................................................................... 9

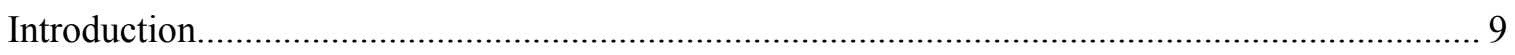

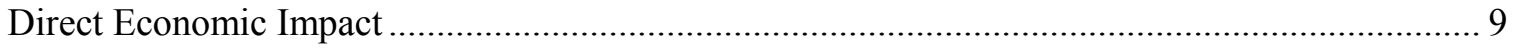

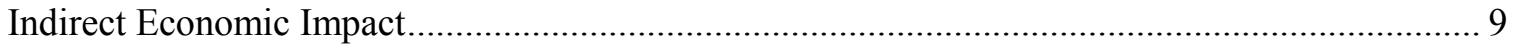

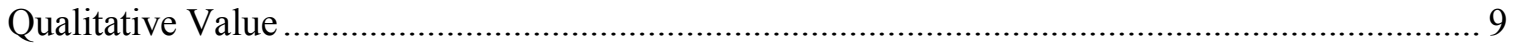

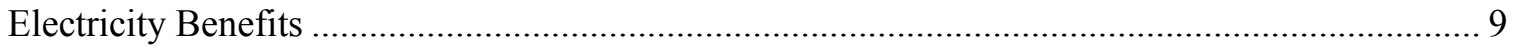

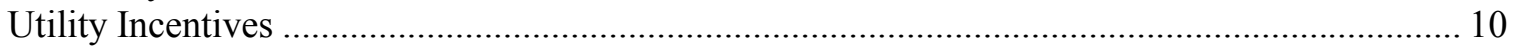

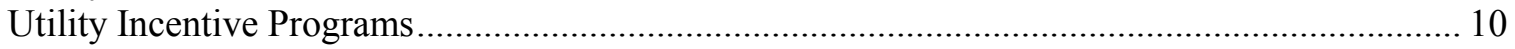

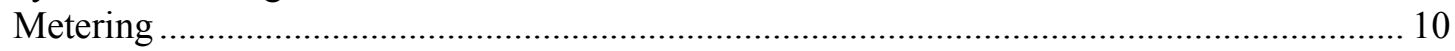

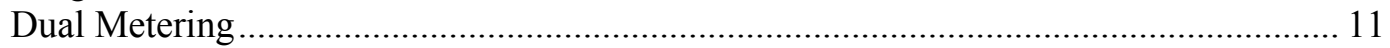

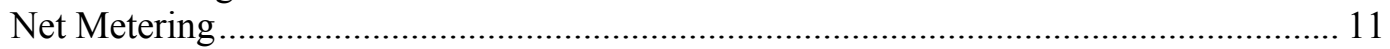

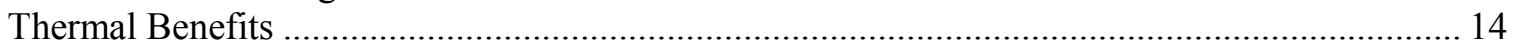

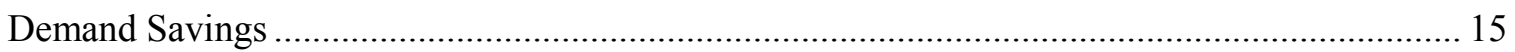

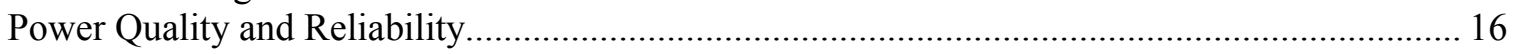

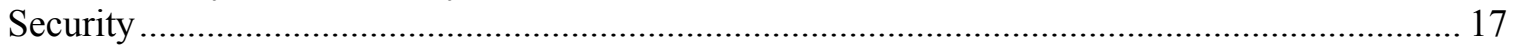

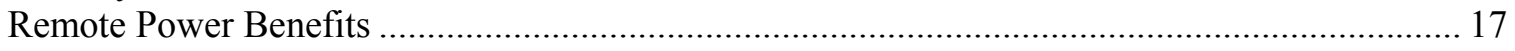

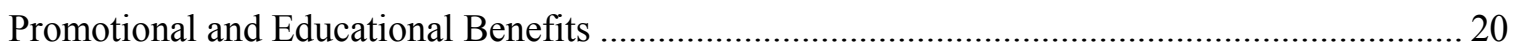

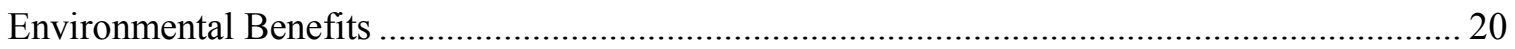

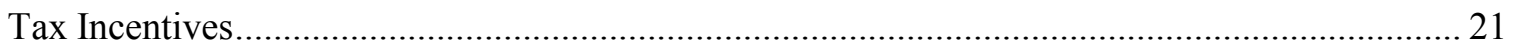

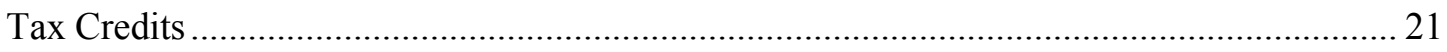

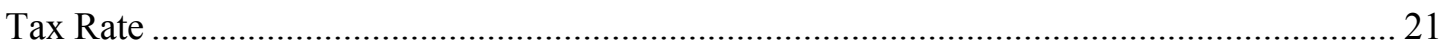

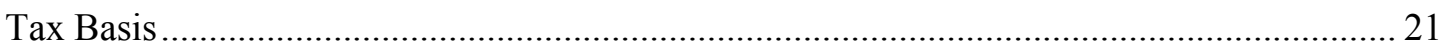

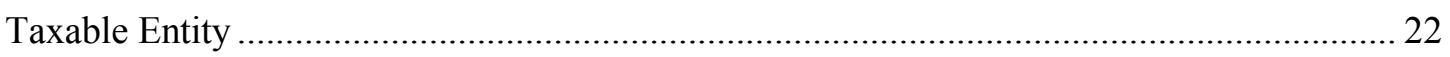

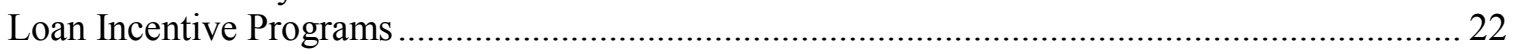




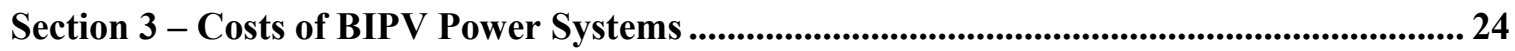

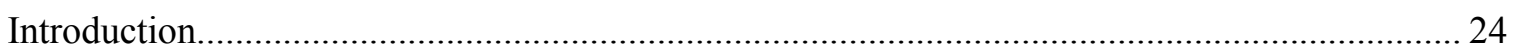

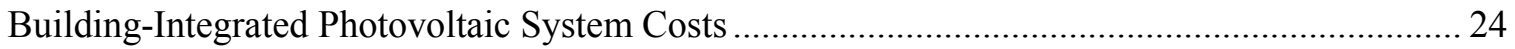

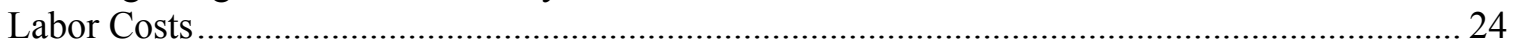

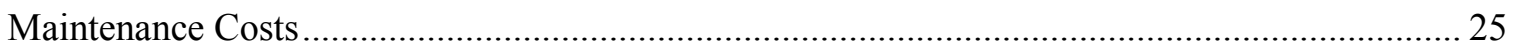

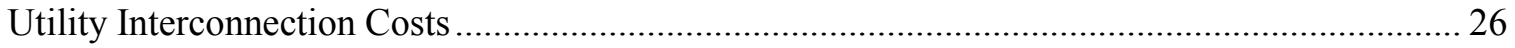

Costs Associated with Building Permits............................................................................... 27

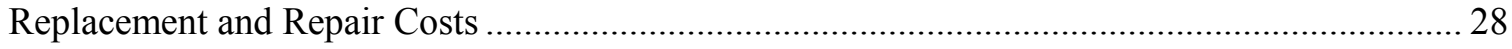

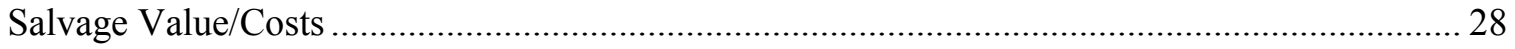

Section 4 - Measurement and Verification for Building-Integrated Photovoltaics................ 29

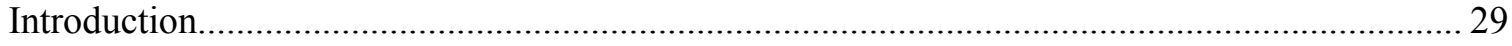

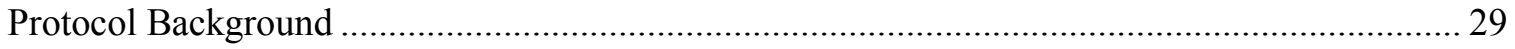

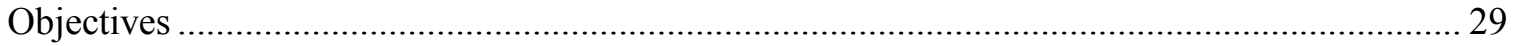

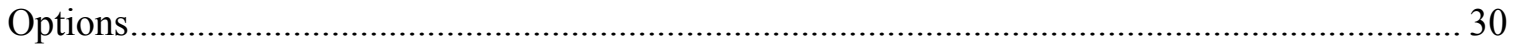

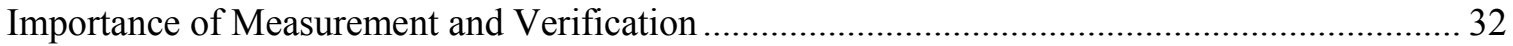

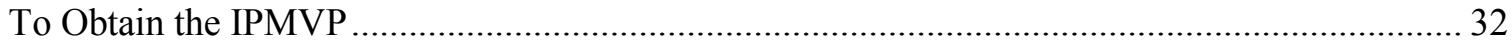

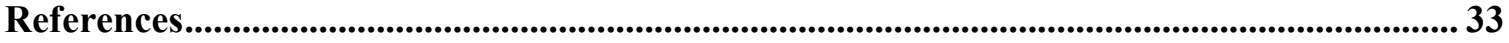

Appendix - Methods of Assessing Capital Budget Decisions.................................................... 36 


\section{Section 1 - Investment Analysis}

\section{Introduction}

This section identifies general methods of investment analysis and explains how they may be applied to the assessment of building-integrated photovoltaic (BIPV) power systems. A major barrier to analyzing renewable energy systems is assembling and presenting the technical and financial data in ways that will help a client decide if a BIPV power system would make economic sense. Economic methods of investment analysis, such as payback period, net benefit analysis, adjusted internal rate of return, and lifecycle cost analysis can be used to evaluate BIPV systems from the standpoint of the owner-occupant, owner-investor, and owner-developer.

\section{Economic Benefits and Costs}

Generally, most architects use some form of quantitative analysis such as net benefit analysis, length of payback period, or internal rate of return as a financial criterion to evaluate a building investment. However, there is a variety of barriers to the widespread investment in BIPV systems according to a survey of American architects. These architects were surveyed at a one-day workshop entitled "Building-Integrated Photovoltaics for Design Professionals," which was sponsored by the National Renewable Energy Laboratory (NREL) and the American Institute of Architects (Wenger and Eiffert 1996). Many respondents indicated that a major barrier to analyzing renewable energy systems is assembling and presenting the technical and financial data to persuade a client that a BIPV system would make economic sense.

Investment evaluations of energy systems generally include an assessment of the projected benefits compared to the estimated costs of the system. The direct financial benefit of a BIPV system is primarily the value of energy generated. These direct benefits may be viewed as:

\section{Projected Benefits $=$ Value of Electricity Generated}

The direct economic costs of a BIPV system may be considered as:

$$
\text { Estimated Costs }=\text { Capital Costs }+ \text { Periodic Costs }+ \text { Replacement Costs }
$$

Quantitative analysis is a tool that facilitates ranking and choosing among investment alternatives. As such, quantitative procedures appear to be straightforward. However, numerous factors influence comparative evaluations. A building owner's economic expectations about future interest rates, inflation, and fuel costs directly affect investment decisions, as can utility interface requirements, environmental regulations, and tax incentives.

When photovoltaic (PV) technology is adapted and used as a building component, as exemplified in BIPV, its economic costs and benefits may be shared between the occupant and the utility company. For a building owner, the added costs of installing and operating a system to generate electricity may be offset by the avoided costs of

purchasing electricity or by selling surplus electricity to the utility company. 
Consequently, guidelines to identify the economic value of a BIPV system can be used to help establish rate precedents and calculate an equitable rate structure for taking electricity from or supplying it to the electricity grid. This can be assessed along with the architectural value and performance expectations of PV as a building component. Then the value of a BIPV system can also be weighed against the indirect economic benefits or qualitative advantages and disadvantages associated with image, public perception, and visual and environmental impact.

\section{Economic Methods of Investment Analysis}

Five relevant economic methods of financial analysis that are often used for making building investment decisions are payback analysis, net benefit analysis, savingto-investment ratio (SIR), adjusted internal rate of return (AIRR), and life-cycle cost (LCC) analysis. This study will assess the usefulness of these methods in evaluating the economics of BIPV.

\section{Payback Period}

The payback period is the minimum time it takes to recover investment costs. The payback period for an energy system is calculated as the total investment cost divided by the first year's revenues from energy saved, displaced, or produced. In payback analysis, the unit of measurement is the number of years to pay back the investment cost. Projects with short payback periods are perceived to have lower risks. Simple payback analysis takes into account only first costs and energy savings at present cost. This method omits several significant cost factors, including the cost escalation rate and the cost of capital. Thus, simple payback analysis can overestimate the actual payback period and, consequently, the length of time to recoup the investment.

The two main variations are payback after taxes and discounted payback. Payback after taxes includes and evaluates marginal tax rates and depreciation schedules. In the discounted payback method, future years' revenues are considered to have less value than current revenues. Discounted payback is the time between the point of initial investment and the point at which accumulated savings (net of the accumulated costs) are sufficient to offset the initial investment costs. Costs and savings are adjusted to account for the changing value of money over time.

For investors who seek rapid turnover of investment funds, the investment increases in attractiveness as the payback period decreases. However, a shorter payback period does not necessarily indicate the most economically efficient investment. An investment with a longer payback period may be more profitable than an investment with a shorter payback period if it continues to yield savings for a longer period.

The payback measure is essentially a break-even measure of system life. Payback can be used to determine the minimum time a system must last in order to recover the investment costs.

The payback method is often used as a rough guide to cost effectiveness. If the payback period is significantly less than the expected system life, the project is likely to be considered cost effective.

\section{Net Benefit Analysis}

Net benefit analysis can be used to express the net difference between the benefits and costs of one energy system relative to an alternative in present or annual value 
dollars. Net benefits, also called net present value (NPV), is the difference between the present value of benefits (revenues or savings) and the present value of costs of the alternatives. A system is cost effective if the net saving or net benefit is positive.

\section{Savings-to-Investment Ratio}

The savings-to-investment ratio can be used to compare savings to costs of one energy system relative to an alternative. The resulting unit of measure is an undimensioned number. For positive net savings, the SIR must be greater than one. The higher the ratio, the greater the savings realized relative to the investment.

\section{Adjusted Internal Rate of Return}

The adjusted internal rate of return is a discounted cash flow technique that measures the annual compound yield from a project, taking into account reinvestment of interim receipts at a specified rate. With this methodology, estimating the cost effectiveness of a project involves comparisons of the calculated AIRR of a project to the investor's minimum acceptable rate of return (MARR). The project is cost effective if the AIRR is greater than the MARR.

The AIRR is calculated by taking the $n^{\text {th }}$ root of the ratio of the terminal value (TV) of all cash flows (except investment costs) to the present value of investment costs (PVI) and then subtracting one [(TV/PVI) $1 / n-1]$. The AIRR may be contrasted with the internal rate of return, which computes the yield on original investment and is calculated by a trial-and-error process that involves selecting compound interest rates and discounting the cash flows until a rate is found for which the net value of the investment is zero.

\section{Life-Cycle Cost Analysis}

In life-cycle cost (LCC) analysis, all relevant present and future costs (less any positive cash flows) associated with an energy system are summed in present or annual value during a given study period (e.g., the life of the system). These costs include, but are not limited to, energy, acquisition, installation, operations and maintenance (O\&M), repair, replacement (less salvage value), inflation, and discount rate for the life of the investment (opportunity cost of money invested). The unit of measurement is present value or annual value dollars. A comparison between the LCC of an energy system to an alternative determines if the system in question is cost effective. If the LCC is lower than that for the base case and in other aspects is equal, and the project meets the investor's objectives and budget constraints, it is considered cost effective and the preferred investment (Ruegg 1990).

\section{Using the Methods for Investment Decisions}

Examples of decisions that may confront a building owner or operator are the following: will a particular BIPV system be cost effective for a specific building? Would other designs and/or sizes of the BIPV system be more cost effective? Given a limited budget to retrofit a building for energy efficiency, 10 alternative modifications (including a BIPV system) are available that together total four times the budget. Which of the ten alternatives should be selected?

While the methods presented can be helpful in making a variety of investment decisions, they are not equally well suited for all types of decisions. All of the methods, 
in most cases, can be used to determine if a BIPV system is expected to be a costeffective addition to a building, other things being equal. For this purpose, the payback method is the least reliable, but in many cases, will also provide a clear indication of cost effectiveness.

For the purpose of designing and sizing BIPV systems, either the net benefits method or the life-cycle cost method is recommended. As long as net benefits increase or life-cycle costs decline as more expensive designs are chosen or as system size is increased, it pays to go to the more costly design or larger system. The saving-toinvestment method and the adjusted rate of return method can also be used for designing and sizing BIPV systems, but it is imperative that these methods be applied to incremental amounts rather than to totals in order to serve as a reliable guide (Ruegg and Marshall 1990).

For the purpose of ranking non-mutually exclusive investment alternatives, the SIR method and the AIRR are the preferred measures. In most cases, choosing projects in descending order of their SIRs or AIRR until the budget is spent will result in maximum returns to the investor. Choice among projects and the designing and sizing of the candidate projects can be combined in an overall optimization approach. 


\section{Example: PV Covered-Parking Systems (Lepley 1997)}

One strategy for reducing the cost of PV systems is to use PV in applications where there is additional value beyond electric power production. In the example of covered parking, structural and land requirements for the PV system are eliminated. For new construction, the PV modules can provide shade and weather protection, resulting in an additional cost credit. In a few applications, the value of the shade may be much higher than the value of the electricity, so the value of the PV system/parking system combination may be as much as $\$ 5$ per watt.

Assumptions:

- $18 \%$ of the full capital cost is needed each year for principal, interest, taxes, and insurance.

- O\&M cost of $\$ 0.01$ per kilowatt-hour ( $\mathrm{kWh}$ )

- Electricity generation of 1600-kWh/year per installed kilowatt $(\mathrm{kW})$

- Electricity value of $\$ 0.10$ per $\mathrm{kWh}$

- One $k W$ covers 1.25 parking stalls.

- Shaded parking costs $\$ 2.00$ per day per parking space.

- Utilization factor is 0.9. That is, assume a parking stall is used only $90 \%$ of the time. Note that covered parking can be very popular at an airport where the climate is extremely sunny and hot.

Based on the above assumptions, the annual value of a 10-kW PV covered-parking system is:

Electricity value

Shade/weather protection value

Total annual value $\$ 9812$

For comparison, the annual cost of a 10-kW installation at $\$ 5,000$ per $k W$ would be:

Capital costs

$\$ 9000$

O\&M costs

Total annual cost

$\$ 9160$

A typical cost is about $\$ 600$ for a covered-parking stall, or $\$ 0.75$ per watt, assuming 800 watts ac per stall. 


\section{Building Ownership Issues}

Given the inherent high first cost and reduced operating costs associated with BIPV power systems, investments are sensitive to and dependent on building ownership issues. The three primary types of building owners (owner-occupant, owner-investor, and owner-developer) differ in their investment criteria and time horizons.

\section{Owner-Occupant}

An owner-occupant expects to own a building for a long time. This positions him or her to control the decisions related to the choice of the energy system. Minimizing the operating costs is in that person's best interests. A higher initial capital investment may be acceptable if it will reduce operating costs. The owner-occupant may make investment decisions during the early stages of building design, construction, purchase, and renovation, and directly experience financial savings, system reliability, and building comfort. But more often, the occupant does not make initial building design decisions.

\section{Owner-Investor}

An owner-investor will purchase and develop property to rent or lease to a third party. To maximize returns on investments, the owner-investor will be interested in minimizing O\&M costs unless the tenant is responsible for the user-energy costs. The owner-investor may consider solar technologies, such as PV power systems, particularly if there are federal, state, or local government tax incentives that provide the basis for an enhanced return on investment.

\section{Owner-Developer}

In this case, ownership is assumed to be temporary, from purchase through development and sale. Investment decisions will include energy-conscious design only if the owner-developer perceives that it will help sell the property. Minimizing development capital costs is important to the owner-developer. Operating costs are not a primary consideration. Given the occasions of high initial capital costs and long-term returns associated with energy investments, there is little incentive to consider energyconscious designs. The owner-developer may be able to capture tax incentives for implementing solar energy systems, but these benefits may not provide sufficient financial incentive to motivate the investment. In an even more negative scenario, the owner-developer, rightly or wrongly, may perceive that this technology and its associated costs will adversely impact the sale of the property and actively avoids the investment.

\section{Building-Integrated Photovoltaics and Building Ownership}

Speculative building developers often base design and investment decisions on first costs only. Future operating costs, including energy costs, may be considered in the financial decision-making process if the building is owner-occupied, or if a potentially lower energy bill can be used as a marketing attraction.

Given that BIPV power systems are capital-intensive investments with low operating costs, in most instances the long-term owner-occupant is best positioned to reap benefits from a system and, therefore, is the most likely customer. 


\section{Summary of Investment Analysis}

Investments in energy systems commit the building owner to current and future cost expenditures. Appraisal methods should account for the relevant costs and compare them on a common basis to the next-best option. Not all costs are factored into the decisions of all building owners; investment decisions are a function of the building owner's time perspective, responsibility for specific cost items, and ability to realize various benefits that may result from BIPV systems. In particular, speculative builders are likely to emphasize first costs over future costs. Additionally, a building owner's ability to finance capital projects may be limited by the ability to borrow or raise equity, or by strategic business objectives.

BIPV systems generally have low operating expenses because of avoided fuel costs; however, the initial system purchase and installation costs make them capital intensive and economically prohibitive when using first-cost analysis. Hence, economic incentives (interest rate buy-downs, utility rebates, metering programs, and tax advantages - including depreciation allowances and financial programs for financing new BIPV construction and renovations) may be needed to encourage their use. Conventional energy systems may initially be less expensive, but depending on recurring fuel costs, may have higher long-term costs.

The evaluation of energy investment alternatives is often done using payback period, NPV, SIR, or AIRR analysis. Primary distinctions among these methodologies are the period over which the costs and benefits are calculated, the unit of measure, and most importantly, their interpretation. Payback period is the minimum time it takes to recover the initial investment. NPV is the net of savings over costs expressed as a timeequivalent value, usually as a lump sum at the present or as a series of annual amounts. SIR is the ratio of savings to costs. AIRR is the annual rate of return assuming reinvestment of interim earnings or savings at a specified rate. LCC is the time-adjusted sum of all time-adjusted costs of a given system over the specified period, and must be compared with the LCC of an alternative system in order to make an informed choice between them. The nature of BIPV building products - to provide electricity in buildings and to act as multi-functional building components - requires a large capital construction cost but no operating fuel cost. BIPV power systems can also accrue non-energy economic benefits over the lifetime of the system. Commonly used evaluation methodologies for traditional buildings, which emphasize first costs or ignore non-energy benefits of BIPV systems may underestimate their true and result in an unreliable or inaccurate decision.

The appendix summarizes the commonly used methods for analyzing investment choices and gives the formulas for their calculation. These formulas do not explicitly include all of the various BIPV-specific costs and benefits that may be relevant to a decision. However, they can easily be modified to incorporate these effects.

\section{Building Life-Cycle Costs Model}

The Building Life-Cycle Costs (BLCC) software program is an economic tool developed during the 1980s by the Office of Applied Economics within the National Institute for Standards and Technology (NIST), which in turn is within the U.S. Department of Commerce. A copy of the BLCC Program User's Guide and Reference 
Manual is available at the Department of Commerce's Web site at www.nist.gov (National Technical Information Service Order Number PB96:199229).

The BLCC software program is designed to evaluate and compare the cost effectiveness of building energy conservation components and systems by quantifying all project-related costs. The lowest LCC of the measured energy options is regarded as the most cost effective. This program is regularly reviewed and revised. It complies with the American Society for Testing and Materials standard practices for building economics with performance measures, including E917 (Practice for Measuring Life-Cycle Costs of Buildings and Building Systems); E963 (Practice for Measuring Benefit to Cost and Saving to Investment Ratios for Buildings and Building Systems); E1057 (Practice for Measuring Internal Rate of Return and Adjusted Internal Rate of Return for Investments for Buildings and Building Systems); E1074 (Practice for Measuring Net Benefits for Investments in Buildings and Building Systems); and E1121 (Practice for Measuring Payback for Investments in Buildings and Building Systems) (NIST 1995).

The BLCC program is generally used to assess energy conservation strategies in federal buildings in the United States. In addition, the Federal Renewable Working Group (RWG) has developed the BLCC Preliminary Costing Guidelines for Renewable and Conventional Technologies (RWG Draft). The guidelines are in the form of a Microsoft Excel spreadsheet that includes costing guidelines for remote renewable projects. Research into the BLCC model indicates that BIPV is relatively easy to evaluate using the additional capital cost of the hardware other costs and benefits.

\section{Recommended Criteria for Cost Effectiveness}

Criteria for cost effectiveness can be subjective depending on the investment decision-maker. Some general guidelines are to define cost effectiveness as any energy project with a SIR greater than one, AIRR greater than the discount rate, LCC lower than that for the next-best alternative energy system, and simple payback period less than the life of the BIPV system.

\section{Example: U.S. Federal Government Evaluation Criteria Used to Establish a Cost Effective Energy Project}

\begin{tabular}{|l|l|}
\hline Evaluation Criteria & Economic Measure \\
\hline Payback Period & Payback Period $<$ Life of System \\
\hline Savings to Investment Ratio & SIR $>1$ \\
\hline Adjusted Internal Rate of Return & AIR $>$ Discount Rate \\
\hline Net Present Value & Net Present Value $>0$ \\
\hline Life-Cycle Costs & Lower than LCC for Alternative \\
\hline
\end{tabular}




\section{Section 2-Benefits of BIPV Power Systems}

\section{Introduction}

The value of BIPV power systems can directly affect the decision-making process. These benefits can be identified and evaluated based on direct economic impact, indirect economic impact, and qualitative value.

\section{Direct Economic Impact}

An integrated building energy system is generally procured through a construction budget. Electricity generated by the BIPV power system creates savings that reduce operating budgets.

A BIPV power system can save the building owner money by reducing construction material costs and electricity costs, providing education, enhancing power quality and power reliability, and providing tax credits. The combined savings may accrue in a variety of budgets that will affect the investor's entire fiscal portfolio performance.

\section{Indirect Economic Impact}

Each building owner has a value related to strategic goals, business interests, or organizational mission. With a multifunctional BIPV power system, additional costs and benefits may accrue and may be hidden or not obvious, due to accounting methods and the directly and indirectly affected budgets. An organization, for example, may be able to assign a credit or value for BIPV technology for environmental emissions reduction if they can be quantified, valued, and even traded. However, if an effect is irrelevant to, or cannot be captured by, a decision-maker, it is generally not included in the investment analysis.

\section{Qualitative Value}

Some benefits of BIPV power systems are simply subjective and are difficult to quantify. For the building owner, a noticeable value of a BIPV power system may be associated with a positive image, public perception, or impact on the built environment when the technology is installed. On the other hand, some may feel the systems detract from the building appearance or constrain the design options due to requirements for building orientation towards the sun. In this study, these benefits or drawbacks are considered subjective considerations. No dollar value will be assigned to them.

\section{Electricity Benefits}

The value of electricity generated by a BIPV power system is determined by the amount of electricity consumed plus the value of surplus electricity generated. Typically, facility electricity bills are paid monthly out of annual operations budgets. The O\&M budget will decrease by using the solar energy source. The value of BIPV electricity generation to the building owner is the difference of the estimated baseline energy bill and the actual cost of the solar energy source. If a backup system is installed, the cost of 
backup fuel must also be taken into consideration when determining the value of BIPV electricity generation.

\section{Utility Incentives}

A variety of utility incentive, energy conservation, and demand-side management programs were successful during the 1980s. These arrangements provided a win-win scenario in which the consumer reduced energy consumption and the utility controlled its load growth. In the United States, the Utility PhotoVoltaic Group (UPVG) is a nonprofit organization funded by the U.S. Department of Energy (DOE). The UPVG comprises over 85 member utilities and is involved in a wide range of activities that supports the development of PV as an energy supply. UPVG provides utility and customer incentives, such as cost sharing, to accelerate the commercialization of PV technology.

As the utilities are faced with the uncertainties and competition associated with deregulation, there is a strong economic incentive to maintain and build on its customer base. Consequently, some utilities offer special customer services, such as "green power" generated by PV. Under these programs, the consumer agrees to pay more for electricity generated from environmentally friendly sources.

Some utility companies have rate structures with differing time-of-day rates. Typically, a BIPV power system will produce electricity during the daytime peak rate hours and provide a high value of avoided electricity costs. If a building is subject to time-of-day usage rates, the economic benefit of PV-generated power during expensive peak rate hours can be included as a direct fiscal impact.

\section{Utility Incentive Programs}

Utility incentive programs may provide innovative financing and contractual mechanisms for energy conservation measures and the implementation of renewable energy technologies. Incentives may include system buy-down or cost sharing, leasing, financing, hosting systems, and net metering.

\section{Example: Rebates}

Currently, a U.S. utility company, Wisconsin Public Service and Wisconsin Power \& Light, offers customer rebates for installing PV power systems. Rebates are available for as high as $\$ 550$ for installing grid-connected $P V$ systems. It is more common for utilities to offer rebates for solar thermal systems. In BIPV projects, utility rebates can be calculated as a credit to the procurement capital cost of a BIPV system.

\section{Metering}

Metering can account for the electricity generated by BIPV power systems or by paying the building owner retail electricity rates or utility avoided cost rates for surplus energy generated by grid-connected BIPV systems. A commercial or institutional building is occupied during daytime hours and generally will consume all the BIPV electricity produced. However, for more than one-third of annual daylight hours, most commercial office buildings and institutional buildings are unoccupied, and surplus energy may be generated on weekends and holidays. If the energy generated by a grid- 


\section{Example: California's Emerging Renewables Fund (Buy-down)}

The 1996 California restructuring law (AB 1890) provided $\$ 540$ million into a Renewable Resources Trust Fund supporting renewable generating technologies. This fund is being used to provide rebates or "buy-downs" to customers who purchase small-scale renewable energy systems. The amount of the buy-down will decline over the life of the program, starting with a block of funds at \$3 per watt and ending with a final block of funds at \$1 per watt. If just half of the funds go toward grid-connected PV systems, then California is likely to have 15 megawatts of new grid-connected PV generation in place within five years. This would roughly double the total existing grid-connected $P V$ generation in the United States.

tied BIPV power system exceeds the requirements for the unoccupied building (power for security, communication, or refrigeration systems) the utility company may purchase the surplus electricity at an agreed upon rate. Net billing, then, bills for electricity provided by the utility less the surplus sold back to the utility and credits the difference if the surplus exceeds the electricity purchased. To encourage private investment in renewable energy technologies, net billing may be mandated by state public utility commissions (PUCs).

The economic value of BIPV metering can be easily identified and measured by the annual or monthly dollar reduction of the facility's energy bill. Net billing accounts for the electricity generated by the BIPV power system by paying the producer for surplus energy either at retail electricity rates or utility avoided cost rates. Retail rates versus avoided costs can significantly affect the economics of BIPV power systems. These two accounting methods, dual metering and net metering, are discussed below.

\section{Dual Metering}

In this accounting method, avoided cost accounts for the utility's marginal cost of fuel and is a relatively low electric rate compared to the retail rates. In practice, the value of photovoltaic electricity is valued relative to coal-fired $\mathrm{kWh}$ power. This requires two meters to be installed on the facility premises: one to account for electricity exported and one to account for electricity imported. This form of metering requires additional hardware and duplicate systems for accounting purposes only. This method does not complement the multifunctional simplicity of BIPV technology.

\section{Net Metering}

Where retail net billing is permitted, the accounting method for importing and exporting electricity uses standard electric meters that can run forward and backward. When the BIPV power system produces more electricity than is consumed in the building, the meter runs backward. The meter registers the net energy, consumed or produced, and the occupant is billed or credited accordingly at the end of the monthly billing period. Along with providing a more efficient accounting method, net metering benefits the utility by reducing marginal energy costs and by using less hardware than dual metering.

Net metering benefits the power generator by providing retail rates for surplus electricity. Over the billing cycle, if the BIPV power system produces less power than 
required, the retail rate is paid to the utility. If an excess of power is produced in the billing cycle, the lower wholesale rate or the rate set by the Public Utilities Commission is typically paid to the system owner.

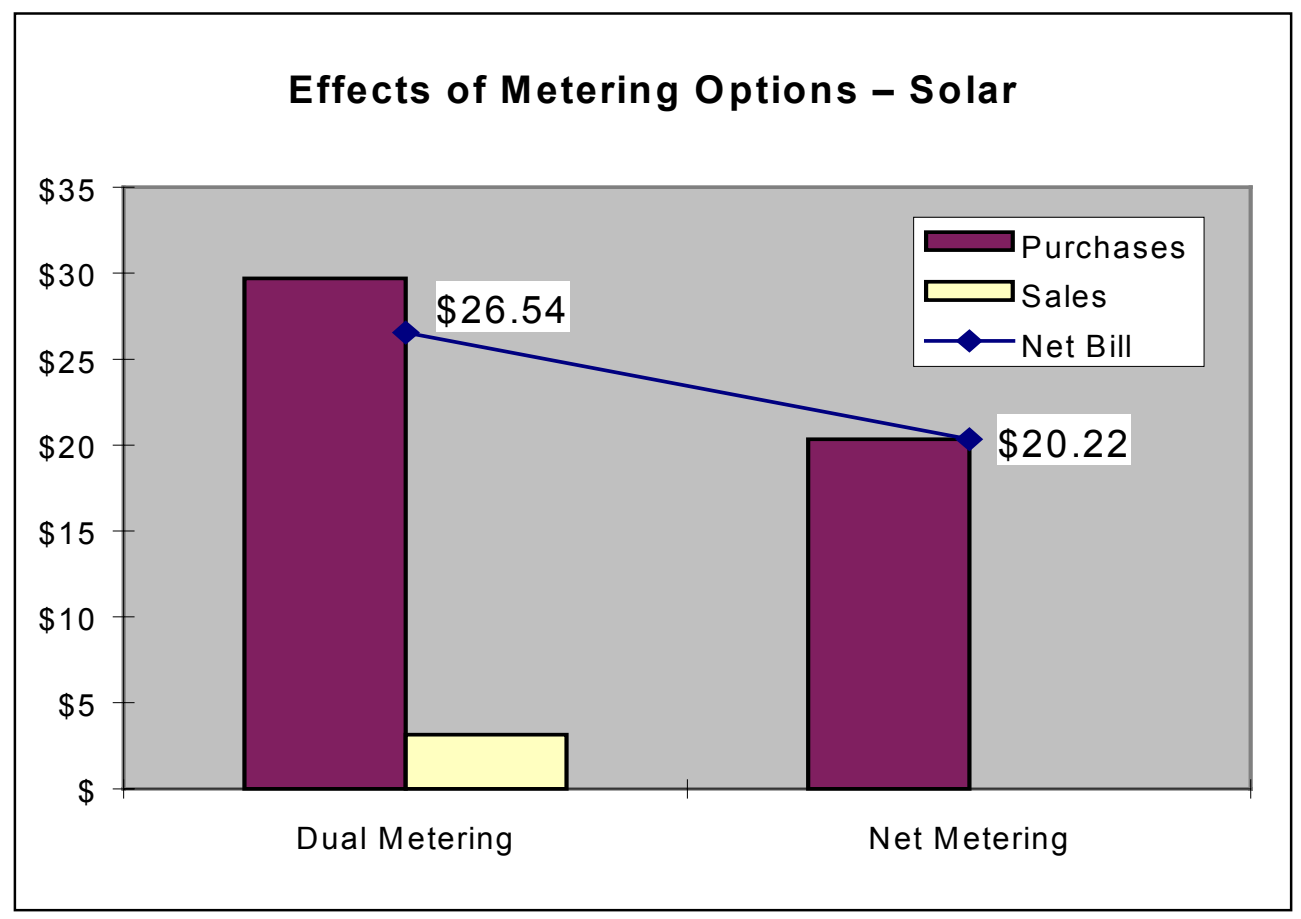

In late 1995, DOE initiated a new program - the National Database of State Incentives for Renewable Energy (DSIRE) - through the Interstate Renewable Energy Council (IREC) to survey each of the 50 states for available information on financial and regulatory incentives. These incentives are designed to promote the application of renewable energy technologies. This information is being developed into a database that will detail the incentives on a state-by-state basis. Access is provided to much of the database via the Internet. By providing this information on such a wide basis, it will be much easier for other states to get needed information for analyzing and replicating successful incentives in their own states.

The North Carolina Solar Energy Center is the principal subcontractor to IREC for collecting and preparing the information. Some of the financial and regulatory incentives are identified by state, end-use sector, technology, and incentive type. The mechanics of financing and regulatory tools are available in the form of files and documents pertaining to statutes, legislation, fact sheets, brochures, and reports.

In the rapidly evolving power industry, DSIRE can be the most effective method of obtaining current information. DSIRE's homepage can be found at http://wwwsolar.mck.ncsu.edu/dsire.htm. The following electronic resources are available: a table of state financial incentives, a table of state programs and regulatory policies, a searchable on-line database, a technical paper on DSIRE, and links for downloading. 


\section{Example: Effects of Net Metering on Utility Bill with Solar PV (Starrs 1999)}

Net metering encourages direct customer investment in small-scale renewable energy systems, simplifies interconnection by avoiding meter replacement, improves economics of small-scale renewables, and reduces metering and administrative costs for the utility. Assumptions for chart below:

- $2 \mathrm{kWp}$ solar PV system

- PV system generates $263 \mathrm{kWh} / \mathrm{month}$

- Residence uses $600 \mathrm{kWh} / \mathrm{month}$

- Retail price is $\$ 0.06 / \mathrm{kWh}$

- "Avoided cost" price is $\$ 0.02 / \mathrm{kWh}$

- PV-to-load ratio is 0.40 . 


\section{Example: Net Metering}

State: New York

Eligible Technologies: Photovoltaics

Applicable Sectors: Residential,

Investor Owned Utilities

Legislative Code: 1997 Assembly Bill 8660, Senate Bill 5400

In the summer of 1997, New York enacted a net metering law for residential PV systems of $10 \mathrm{~kW}$ or less. A similar law was vetoed in November 1996 over concerns about interconnection safety issues. New York's new net metering law also includes an income tax credit allowing residential customers to claim a credit of $25 \%$ of the cost of a qualifying $P V$ system. The maximum system size for a system is $10 \mathrm{~kW}$ and utilities are obliged to accept customers into the net metering program on a first-come, firstserve basis until the capacity signed up for net metering equals $0.1 \%$ of the utility's 1996 peak demand. Individual utilities, however, can choose to allow a greater capacity to enroll in net metering. At the end of each month, net excess generation is credited toward the following month's bill. At the end of the annual billing cycle, if there is any net excess generation by the customer, consumers are paid the utility's avoided cost for that generation.

Contact:

Jeffrey Peterson

New York State Energy Research

and Development Authority

Energy Resources
Corporate Plaza West

286 Washington Avenue Extension

Albany, NY 12203-6399

Phone: (518) 862-1090

Fax: (518) 862-1091

\section{Thermal Benefits}

The energy generated by the BIPV power system can be evaluated by assessing the cost of surplus electricity generated plus the system's energy contribution to the building's thermal performance. As such, the BIPV power system can be designed according to the building's heating, cooling, and daylighting loads. The system can also be deliberately oversized to generate surplus energy, depending on how it is valued by the utility and how much it costs to generate. The added costs associated with the hardware and design of hybrid BIPV/thermal systems would necessitate a careful economic evaluation. Empirical data on hybrid system performance and benefits are currently limited. 
One of the ways BIPV power systems may contribute to a building's thermal performance is through the thermal effect of the shading function on air conditioning loads, which a BIPV awning system provides during the summer. In contrast to shading, the heat cogeneration of a BIPV hybrid system in the winter provides another contribution to a building's thermal performance. This heat is produced when ambient air is vented behind the BIPV glass panels to cool the solar cells. (PV cells perform more efficiently at lower temperatures.) The captured warm air may then be used to preheat water or air for building services.

\section{Example: Cooling Panels and Preheating Water-Applebee's Restaurants}

DOE's PV:BONUS (Photovoltaics: Building Opportunities in the United States) Program sponsored the development of a BIPV/thermal hybrid system for the Applebee's Neighborhood Grill and Bar in Salisbury, North Carolina. Innovative Design engineered the system, and the North Carolina Solar Energy Center is monitoring its performance. The BIPV overhead glazing system has fans operated by the PV system that draws hot air off the back of the BIPV panels through an air-towater heat exchanger to reduce the restaurant's energy demand for producing hot water. Preliminary estimates project less than a 10-year payback for this PV/solar thermal system.

\section{Demand Savings}

Demand savings offers an opportunity to maximize the economic performance of BIPV power systems. Utilities apply a demand charge relative to the peak energy load for a building. A periodic average reading of the building's electrical consumption (e.g., every 15 minutes) determines the peak electrical demand. BIPV power systems are subject to climate and weather conditions - a passing cloud may diminish the system's performance in an instant and the demand savings would not be realized. Therefore, having no backup storage system, such as a battery bank, causes the system to yield uncertain savings. It should be noted that a backup system will also incur an additional cost for design, hardware, maintenance, and battery replacement. At that point, the demand savings benefit of the backup system must be weighed against its additional costs.

\section{Example: Cooling Panels and Preheating Air - Aerni Fenster Factory}

In Europe, the first documented building with a hybrid BIPV/daylighting/thermal system is the Aerni Fenster Factory in Switzerland. In 1993, the hybrid BIPV system produced $70 \%$ of the combined electrical and thermal requirements of the factory. The BIPV system is composed of an 8- $\mathrm{kW}$ BIPV façade and a 53-kW BIPV skylight system. By cooling the backside of the panels with ambient air, the equivalent of $115 \mathrm{~kW}$ of thermal power is captured to heat the factory. This significantly increased the economic performance of the PV/solar thermal system. 
Under the PV:BONUS Program, the University of Delaware's Center for Energy and Environmental Policy and the Applied Energy Group have developed a dispatchable peak-shaving system with battery storage to reduce the time-of-day charges. This system could also be designed and sized to reduce demand charges. It is currently being tested and monitored in five locations throughout the United States.

Additionally, the cost analysis of the peak shaving system conducted by Kiss \& Co. Architects (1995) estimates that demand charges may be reduced by $20 \%$ of the PV system capacity.

\section{Power Quality and Reliability}

The measure of value attributed to electric power quality and reliability are dependent upon the operations of a facility. Power quality problems, such as equipment incompatibility within the supply of electrical power reflect system disturbances that can cause equipment malfunctions and power outages. A power quality problem most likely exists if the power supplied to a piece of equipment is subject to high levels of fluctuations, harmonics, sags, swells, dips, spikes, flickers, and outages, and the equipment cannot handle these faults without shutting down or being damaged. BIPV power systems can be designed to augment power quality by serving a dedicated load. Unfortunately, the value of power quality may be difficult to quantify. It can be increased to ride over a brownout if the PV system provides voltage support at the load (Coles et al. 1995).

To achieve power reliability, uninterruptible power supply (UPS) systems are designed and incorporated into building energy systems to protect specific equipment or critical loads from power interruptions. The additional equipment required include batteries, a storage area, controllers, and associated electronics. A BIPV power system could similarly be designed and sized to serve an isolated load in the building that would automatically separate from the utility grid if a line disturbance or power outage is detected (Coles et al.). The benefit of such a system can be expressed as the avoided cost of an emergency backup power source.

Studies have been conducted on the additional value of PV as an emergency power supply for reliability (Byrne 1997, 1994). A device has been designed that can shave peak electricity demand and switch to a UPS system when a power outage occurs (Byrne). Power quality and reliability are the benefits of such a system. As with demand savings and UPS, additional hardware must be purchased for a reliable power benefit of a BIPV power system. The specific battery storage capacity would have to be engineered and sized to meet the building's needs and energy loads. 


\section{Example: Standards}

Having an infrastructure that supports quality hardware and skills standards may reduce BIPV cost. Increased quality and reliability can provide financing organizations with a means to more accurately assess their risk in supporting $P V$ projects. The Global Approval Program for Photovoltaics addresses standards for PV systems based on existing component standards and includes a testing program to certify the systems at qualified laboratories. The Institute for Sustainable Power, Inc., has been working to qualify the training resources for the human component of the industry. More information regarding certification in the PV industry can be found on World Wide Web at http://www.pvpower.com.

\section{Security}

The concern for security can range from petty vandalism to international terrorism. BIPV technology can play a role in preventing such crimes. The U.S. State Department is responsible for maintaining U.S. embassies in more than 150 countries. Often, frequent power outages or the threat of terrorism requires special security systems in developing countries. Typical UPS systems operate within a brief three-second to three-minute time frame. PV power systems with accompanying battery storage can provide long-term backup power for days. The State Department is evaluating the opportunity to install PV systems at embassy facilities around the world. The value of the PV power system providing security, which would not be obtainable by any other means, could offset the current market cost of the system.

\section{Example: Security}

PV power has enabled the U.S. Department of Interior's (DOI's) Bureau of Land Management (BLM) to dramatically increase security and reduce vandalism at campsites in remote locations. Volunteer hosts typically care for the campsite and ensure that campers pay a user fee for the facility. Without a volunteer host, individual campers are left to the honor system to pay user fees. Because of the convenience of electricity provided by the PV power systems, the hosts are staying longer. When present more often, they can ensure collection of more user fees while deterring vandalism.

The presence of a campground host saves the Moab District more than $\$ 8,000$ a year in the avoided costs of prevented vandalism in each of three campground sites along the Colorado River corridor. BLM estimates this saving resulted in a one-year payback period for each PV system (Duncan 1997).

\section{Remote Power Benefits}

In a remote power situation, the avoided cost of grid-line extension can be evaluated as a benefit of a BIPV power system. The benefit is especially attractive if the customer will bear the cost of the utility line extension. In this instance, BIPV power systems will have greater avoided costs, depending on location. 
Example: Typical Cost Estimates for Grid Connections to Remote Locations

\begin{tabular}{|l|l|}
\hline Service & Fee \\
\hline Installing a power line & $\begin{array}{l}\$ 1,000 \text { to } \$ 2,000 \text { fee (one-time installation fee } \\
\text { includes meter and service connections) }\end{array}$ \\
\hline Each additional pole & $\$ 500$ to $\$ 1,000$ every 150 feet $(45.72$ meters) \\
\hline Transformer & $\$ 400$ to $\$ 800$ each \\
\hline Underground power line & $\begin{array}{l}\$ 3 \text { to } \$ 10 \text { per foot (per 0.30 meter) under asphalt } \\
\text { or concrete }\end{array}$ \\
\hline
\end{tabular}

Source: Urban Consortium Energy Task Force, 1995.

Often a small power generator can serve the remote facility load more cost effectively than a utility grid-line extension. Diesel and propane power generators with optional battery storage have typically been used at remote sites. The cost of transporting this fuel to a remote area can be taken into consideration as well as the reduced costs of the risk of environmental cleanup. Diesel generators often create noise proportional to the power being generated. Sound transmission depends on the acoustical characteristics of the generator building. The U.S. Department of Labor's Occupational Safety and Health Administration (OSHA) provides guidelines (OSHA 1910.95) on acceptable sound levels to protect against the effects of noise exposure (measured in decibels determined by octave band analysis). Additionally, there is value in reducing noise pollution where occupants and users desire a natural, quiet setting. 


\section{Example: Reduced Transportation Costs}

The Currin studies found that the cost of fuel delivery for a small power generator in a remote location was being passed on to the consumer in the form of a delivery charge or operations charge. Often, because of the remoteness of the site, fuel might have to be transported by boat or special vehicles. The cost of special delivery can be calculated based on gallons delivered and transportation costs. The fuel delivery cost was added on as a cost per gallon (per liter) then could be calculated to cost per $\mathrm{kWh}$ based on the efficiency of the generator.

\section{Example: Reduced Risk of Environmental Cleanup Costs}

Two benchmark studies by the Currin Corporation compared a diesel generator to a $P V$ power system. These studies indicate that a solar generator may (1) present less risk of environmental cleanup, (2) reduce fuel transportation costs, and (3) drastically reduce noise pollution as compared with diesel.

In these studies, the risk of a minor or major diesel fuel spill on land or water was identified along with the costs for fuel spill cleanup. In these studies, these costs were identified and then averaged as a "spill risk" cost per gallon of fuel delivered and were included in the economic evaluations.

\section{Example: Value of Reduced Generator Noise Pollution}

The cost estimate for noise pollution can be calculated on the bases of fuel consumed per season, number of visitors per season, and per diem expenses. A subjective iudgement on the negative impact on the quality of the visit can also be considered. For the National Park Service (NPS) Windigo Ranger Station, the benefit was determined to be $\$ 0.50 /$ gallon (\$0.13/litre) of fuel consumed.

Source: Currin Corporation, 1995. 


\section{Promotional and Educational Benefits}

A BIPV power system may have promotional and educational benefits. In 1994, a BIPV façade was used to renovate an office building in Berlin. The environmental friendliness aspect of this building technology was used as a marketing tool that seemed to enhance office space leasing. According to a May 1996 International Energy Agency report, "Despite surplus office area in Berlin, the Okotec-building was almost completely rented immediately following several press publications referring to the PV façade." This benefit could be treated as lost-rent avoided in a dollar value LCC analysis, provided the impact of the BIPV system on the probability of renting the space could be quantified.

As another example, a BIPV installation on the Digital Equipment Headquarters in Geneva, Switzerland, may have been used as part of a promotional campaign by an environmentally conscious company. The installation may have been funded directly out of a public relations budget. If so, the value of the installation would then be identified as the benefit to the company's public relations. If this value could not be assigned a monetary value, it could be carried as a qualitative benefit to be considered in addition to quantitative effects.

Technology demonstration provides education and outreach that corresponds with some agencies' missions. If education is the primary purpose of the system, it is the deciding factor in using the technology. The economics of the system performance become ancillary. Cost justification, therefore, may not be a requirement when a technology is used for demonstration.

\section{Environmental Benefits}

When generating electricity, BIPV power systems produce no harmful environmental emissions. A stakeholder can account for avoided environmental cost associated with not using fossil fuel-generated power. This value can be included in an LCC analysis. However, this value should not be considered when assessing decisions in which environmental effects plan no role (e.g., Energy Savings Performance Contracting would not include qualitative environmental benefits that do not directly affect cash flow in the economic analysis).

\section{Example: Emissions Costs}

According to DOI, NPS, Denver Service Center Guideline 82-1, in all LCC assessments, environmental emission costs will be part of the analysis. This is applicable to new construction, renovation, and power system replacement. NPS, DSC Guideline 82-1, Amendment No. 3, quantifies the environmental emissions cost of electrical power generation and the resulting emission releases.

The NPS has determined that the environmental cost associated with carbon dioxide $\left(\mathrm{CO}_{2}\right)$ emissions to be $\$ 0.004 / \mathrm{lb}(\$ 0.0088 / \mathrm{kg})$, sulfur dioxide $\left(\mathrm{SO}_{2}\right)$ emissions to be $\$ 0.75 / \mathrm{lb}(\$ 1.65 / \mathrm{kg})$, and nitrous oxide $\left(N O_{x}\right)$ emissions to be $\$ 3.40 / \mathrm{lb}(\$ 7.48 / \mathrm{kg})$. 


\section{Tax Incentives}

It is government tax policy that determines whether there will be tax incentives. Tax incentives are designed by public policymakers to encourage private capital investments that might not ordinarily occur. Solar energy tax credit legislation is designed to stimulate the social and institutional acceptance and accelerate the economic development of the industry by encouraging private investments in PV power systems.

Solar energy tax legislation can influence the development of technical expertise through industry and trade association labor certification, bonding requirements, product quality, warranty and guarantee coverage requirements, and system certification to meet building codes. This legislation can be technically specific and disseminate educational and state-of-the-art information about BIPV power systems. Federal regulations can reduce the investment risk to the lender and act as a financial incentive for the consumer or manufacturer to invest in the technology.

The four categories of U.S. taxation incentive programs that may apply to BIPV power systems - tax credits, tax rate, tax basis, and taxable entity — will be discussed in this section.

\section{Tax Credits}

Tax credits permit a percentage of expenditures to be deducted from the net taxes owed to the government. In the United States, the taxation parameter is divided into federal, state, and local tax obligations. Currently, the federal government allows a $10 \%$ tax credit to offset the cost of PV power systems in commercial buildings. The Federal Solar Energy Tax Credit is augmented by state tax policies, based on local initiatives. There is a variety of tax legislation among the 50 states. For example, North Carolina has instituted a 35\% income tax credit allowance for commercial buildings with PV power systems; however, South Carolina has no such legislation.

\section{Tax Rate}

A reduction to the tax rate can provide a financial advantage in three ways: (1) it can exempt certain activities, products, or entities from taxation, or tax them at a lower rate than their market substitutes; (2) entire entities (e.g., some publicly owned electric utilities) may be exempt from federal income tax even though they compete with other providers of the same service that are taxed; and (3) a lower tax rate may permit a particular type of firm to pay a lower percentage tax on certain activities (e.g., lower tax rates on capital gains).

\section{Tax Basis}

The tax basis can be reduced by decreasing the taxable income on which a given percentage tax is applied. This is accomplished by either accelerating the timing of the tax deduction or by excluding portions of income subject to taxation. Firms may be allowed to deduct costs of PV investments from taxable income much faster than the investments actually depreciate. The reduction in current taxes is greater than the reduction in future taxes. The current tax savings (e.g., accelerated depreciation on plant and equipment) can also be invested and earn interest. 


\section{Examples: Tax Credits}

\section{Property Value}

In California, a BIPV system does not add to the assessed property value until the property is sold (Freedman 1995, SIJ 1993).

\section{Sales Tax Recovery}

In Connecticut, sales tax paid for a BIPV system can be recovered when filing an annual tax return (SIJ 1993, Freedman 1995).

\section{Accelerated Depreciation}

In Texas, a commercial business may apply an accelerated depreciation of franchise tax over five years for businesses that invest in the installation of a BIPV system (Freedman 1995, SIJ 1994, SIJ 1993).

\section{Reduction in Tax Basis}

In Hawaii, the net income tax credit for BIPV systems is $35 \%$ or $\$ 1,750$ maximum for single family residence, and $35 \%$ or $\$ 350$ maximum for multi-unit buildings, and $35 \%$ for commercial buildings with no maximum (Freedman 1995, SIJ 1993).

\section{Taxable Entity}

Altering the taxable entity will affect the definition of a taxpayer. This change may enable profits to be offset by losses and have a beneficial effect on tax calculations. Exceptions to rules on consolidating tax returns can give rise to subsidies, which allow profits to be shifted in a large, vertically integrated corporation (such as occurs in the oil industry). For example, when the taxable entity is difficult to define and transactions between divisions are done at artificially set transfer prices, profits can be shifted among divisions and countries to minimize the tax burden.

\section{Loan Incentive Programs}

The federal government can act as a risk-absorbing agent to allow the private sector loan recipient to benefit from the government's economy of scale in raising funds and insuring risks. This reduces the capital cost by directly subsidizing interest rates, by eliminating the premium charged by the lender for default risk, by allowing favorable repayment terms, or by operating insurance programs at a loss.

The U.S. federal government has authorized several such financing mechanisms for solar energy systems. These mechanisms are summarized in a 1998 booklet, The Borrower's Guide to Financing Solar Energy Systems: A Federal Overview, which has been prepared by the DOE in collaboration with the U.S. Departments of Agriculture, Housing and Urban Development, and Veterans Affairs, as well as the Environmental Protection Agency and the Small Business Administration (SBA). Staff at the Federal 
National Mortgage Association (or Fannie Mae) and the Federal Home Loan Mortgage Corporation (or Freddie Mac) also provided valuable input. This booklet provides an overview of authorized programs that may make it easier and more affordable for building owners to finance BIPV and other solar energy power systems.

In a few states (such as California), energy offices, bureaus, or commissions may offer financial programs with low-interest loans to encourage the use of renewable energy technologies. For example, a commercial business eligible for such a loan may receive a sizeable financial advantage that offsets the system's high capital cost. A lower interest rate can reduce payments over the term of the loan. This affects the overall economic performance of a BIPV power system investment.

An investor or financier may perceive a BIPV power system to have a greater risk than traditional grid-supplied electricity. Legislation provides the means and opportunity to (1) specify regulations that can minimize the risk associated with a new technology to satisfy the risk assessment requirements of lending institutions and (2) provide a financial incentive for building owners to make private investments.

\section{Example: Loan Incentive Programs}

\section{Interest Rate Reduction}

A one-eighth point reduction on a residential home loan is available through the Environmental Protection Agency's Energy Star ${ }^{\circledR}$ Mortgage Program. A \$20,000 $B I P V$ roof system on a $\$ 200,000$ home would result in a reduction of the interest rate on the full \$220,000 mortgage over the life of the loan. Hence, the BIPV installation would reduce not only the home owner's monthly utility bill, but also the mortgage bill.

\section{Increased Debt-to-Income Ratio "Stretch"}

This ratio compares a borrower's expenses and income to determine the borrower's ability to meet monthly financial obligations. The Veteran's Administration allows the loan value to be increased up to $\$ 6,000$ if the increase in the mortgage payment is matched by the reduction in the utility bill. This allows the veteran to borrow more money to install solar equipment.

\section{Loan Guarantee}

The U.S. Small Business Administration provides a loan guaranty program [7(a)], which transfers the risk of borrower nonpayment, up to the amount of the guaranty, from the lender to the SBA. The business applying for an SBA loan is actually applying for a commercial loan with an SBA guarantee. The government will reimburse the lender for any loss up to the percentage of $S B A$ 's guarantee. These types of loan guarantees encourage lenders to provide funds for solar systems even though the lenders are unfamiliar with the technologies. 


\section{Section 3 - Costs of BIPV Power Systems}

\section{Introduction}

This section characterizes the relative costs of BIPV power systems for the building owner. Limited published data is available on BIPV power system costs. A preliminary survey conducted in this research indicates that there is a wide variation in cost estimates provided by various manufacturer marketing representatives. Consequently, a variety of vendor bids should be gathered and reviewed prior to making an investment decision.

The BIPV power system cost depends on the type and size of the system, on current PV technology, and on whether a custom product or a standardized manufactured product is used. Two primary types of commercial BIPV products - façades and roof materials - are available for both new construction and renovation projects. BIPV façade systems include laminated and patterned glass, spandrel glass panels, curtain wall glazing systems, cladding systems, and awning systems. These products can displace traditional construction materials. Roofing systems include BIPV shingles, tiles, metal roofing, exterior insulation roof systems, and atrium or laminate roof systems. These products can displace traditional construction materials or be sold as enhanced construction materials. As such, the added cost for a BIPV power system should be used in economic assessments rather than the full costs, including those that would be incurred regardless of the BIPV system. If, after a preliminary screening, the economics are favorable for a BIPV power system investment, a formal bid from the system supplier can be used to evaluate the system cost and benefits in more detail prior to purchase. Subsequently, the total BIPV system cost can be compared to conventional building component costs to determine the added cost of the BIPV system.

\section{Building-Integrated Photovoltaic System Costs}

BIPV systems are composed of PV modules and balance of system components, which include inverters, an electricity storage system and/or a grid-metered connection, fault protection, cabling, and wiring. These costs, as well as the costs of integration design and installation, should be evaluated in comparison to the traditional construction products and systems in order to determine the added investment cost of the BIPV system.

Currently, many U.S. BIPV manufacturers are in early stages of technology development and do not have the capacity to take advantage of quantity purchases of materials and of large volume production in order to offer lower-priced BIPV components and systems; nevertheless, there has been a decline in the cost of PV technology over time due to technical advances. In addition, the industry and government foresee further cost as demand for PV technology increases internationally and manufacturing economies of scale increase.

\section{Labor Costs}

Because of low demand and low manufacturer production volumes in the United States, early BIPV power system demonstration projects have incurred high design and final product costs. The time and money required for the electrical and mechanical 
engineering and the installation methods have been relatively disproportionate to the total cost of the system (Kalin 1994). The standardization of BIPV building products and the simplification of system engineering, design, and installation methods will most likely reduce labor costs of future BIPV power systems.

Currently, and until BIPV becomes a mainstream technology, there is an added labor cost of architectural design, engineering design, and installation. However, with technical supervision, traditional building tradesmen (including glaziers, roofers, sheet metal workers, and electricians) can install BIPV power systems. A manufacturer may supply the components of a BIPV system to the technical supervisor or a system integrator may be contracted separately. The cost of additional, specialized technical supervision over traditional craftsmen should be included when a BIPV power system is evaluated.

\section{Maintenance Costs}

Maintenance costs can be significant in determining the long-term cost effectiveness of an investment. In lieu of including a major capital replacement as a standard item in the financial evaluation, the analysis may instead include maintenance costs deemed sufficient to keep the system operational over the time horizon of the decision-maker. Alternatively, system replacements may be included in the analysis. For the purpose of this guide, it is assumed that all repairs and replacements will be treated as part of maintenance costs. As in the case of other costs, maintenance costs should be treated in terms of the added maintenance costs attributable to the BIPV system rather than the total building maintenance costs. The BLCC model includes a provision for maintenance costs.

Manufacturers recommend periodic system checks and cleaning as part of a preventive maintenance routine. This includes regularly clearing away any debris and cleaning the BIPV surfaces exposed to the environment, which should be completed more often if the environment is particularly dirty. To determine the optimal cleaning

\section{Example: Professional Review Costs}

A homeowner in New Mexico recently asked his utility for the forms needed to interconnect his residential PV system and received a 36-page contract (not including the requisite exhibits). Faced with the prospect of hiring an attorney and a licensed engineer in order to get a small, 2-kW PV system interconnected, it is not surprising that homeowners like this one frequently abandon their projects at this point. A review by an engineer and an attorney can incur an additional \$1,000 to the project cost.

The solution to the interconnection problem is uniform adherence to interconnection standards developed by recognized national authorities, including the National Electrical Code, Underwriter's Laboratories procedures, and the Institute of Electrical and Electronic Engineers recommended practices. This can happen through voluntary acceptance by utilities or by legislative or regulatory mandates (Starrs and Wenger 1998). 
schedule, the trade-off between the cost of cleaning the system to maximize power output and the value of the lost electricity without cleaning the system can be assessed. In some instances, particularly in high-rises or buildings with unusual geometric shapes, cleaning the system may be more costly than the reduced power output. As a rule of thumb, visual inspection of essential components, based on an inspection checklist provided by the manufacturer, should be made every six months. The utility meter and bill can be reviewed monthly to determine whether output from the system is dropping (adjusting for seasonal and other mitigating factors). If this simple screening indicates poor system performance, there should be further investigation.

Annual detailed electronic testing is recommended. The string voltage can be tested with a voltmeter. (A string that shows low voltage relative to the others may have a faulty module or connector.) A data logbook should be maintained by the facility maintenance personnel to record system performance, maintenance, and string voltage. Service adjustments and repair can be provided by the manufacturer, system integrator, distributor, or potentially by the utility company.

The labor costs for maintaining the system should be included in the economic analysis. Means Facility Construction Cost Data can be useful for estimating labor costs. Using the current Means data, for example, will result in an hourly salary of $\$ 26.60$ for a facility services engineer to maintain the system. The projected maintenance costs will be 8 hours per year $(\$ 212.80)$ for a small system (less than $5 \mathrm{~kW}), 16$ hours per year $(\$ 425.60)$ for a medium system (less than $100 \mathrm{~kW})$, and 24 hours per year $(\$ 638.40)$ for a large system (over $100 \mathrm{~kW}$ ). Some manufacturers offer complete turnkey systems as well as optional service and maintenance contracts. Additionally, service contracts or personnel training and maintenance schedules can be negotiated as part of the project contract. Typically, training the facility engineer to service the system in-house will minimize the cost for system maintenance. Maintenance costs may comprise a routinely recurring part and a non-recurring part, each of which can be separately included in the BLCC model.

\section{Utility Interconnection Costs}

Utility interconnection costs are associated with the specific requirements determined by each state. State PUCs have widely varying attitudes toward additional requirements, and their requirements vary. Costs can include large interconnection fees, net metering tariffs, metering calibration charges, engineering study fees, and standby charges. Additional requirements for liability insurance, property easement, legal indemnification, record-keeping of all O\&M, and additional protection equipment will contribute to even greater utility interconnection costs. The relative cost of meeting these requirements is much greater for small systems than it is for larger systems. The costs of these requirements offset to some extent the incentive provided by net metering and may deter customers - particularly small power customers-from participating. 
Example: Public Utility Liability Requirements

\begin{tabular}{|l|l|}
\hline Public Utility Commission & Liability Requirement \\
\hline Oklahoma, California, New York & Not a requirement \\
\hline Maryland, Nevada & Prohibits \\
\hline Idaho & Requires \$1 million liability insurance \\
\hline
\end{tabular}

A set of uniform interconnection standards can facilitate the implementation of net metering nationwide and will hopefully reduce this barrier to grid-connected BIPV. For example, two California investor-owned utilities originally structured net metering contracts that set a substantial monthly customer charge and standby charge. This essentially made net metering unattractive until the California PUC banned the imposition of customer charges (Wan 1996). The renewable industry strives to work closely with utilities and standard-setting organizations in developing such standards.

\section{Costs Associated with Building Permits}

A building permit is required before any constructing, adding, moving, or altering any building. Electrical permits are required for new, remodeled, or up-graded structures. Some of the costs include fees for land disturbance, residential or commercial building permit fees, and reinspection fees. Building permit fees vary from county to county and are based on the estimated cost of construction or square footage; therefore, permit fees may be increased by the addition of a BIPV system. Contact local land use and building design officials to identify specific project requirements, and use only added permit cots in an economic analysis of a BIPV system.

\begin{tabular}{l} 
Example: Permit Fees \\
\begin{tabular}{|l|l|}
\hline Total Valuation & Fee \\
\hline$\$ 0$ to $\$ 3,000$ & $\$ 25.00$ \\
\hline$\$ 3,001$ to $\$ 50,000$ & $\begin{array}{l}\$ 25.00 \text { for the first } \$ 3,000, \text { plus } \$ 6.00 \\
\text { for each additional thousand or fraction } \\
\text { thereof, to and including } \$ 50,000\end{array}$ \\
\hline$\$ 50,001$ to $\$ 100,000$ & $\begin{array}{l}\$ 307.50 \text { for the first } \$ 50,000, \text { plus } \$ 5.00 \\
\text { for each additional thousand or fraction } \\
\text { thereof, to and including } \$ 100,000 .\end{array}$ \\
\hline$\$ 100,001$ to $\$ 500,000$ & $\begin{array}{l}\$ 557.00 \text { for the first } \$ 100,000, \text { plus } \\
\$ 4.00 \text { for each additional thousand or } \\
\text { fraction thereof, to and including } \\
\$ 500,000 .\end{array}$ \\
\hline$\$ 500,001$ and up & $\$ 2,157.00$ for the first $\$ 500,000$, plus \\
& $\$ 3.00$ for each additional thousand \\
or fraction thereof.
\end{tabular} \\
\hline $\begin{array}{l}\text { NOTE: } \\
\text { 2. Construction cost estimated at } \$ 50.00 \text { per square foot } \\
\text { 3. Certificate of Occupancy at } \$ 10.00 \text { each }\end{array}$ \\
\hline
\end{tabular}


Software by Governmental Data Services, Inc. (GDS), provides for complete contractor management, including entering building permits and calculating permit fees. Access to permits is given by address, legal description, owner name, water billing number, water meter serial number, or contact name. (To learn more, visit the GDS Web site at http://www.fastlane.net/ gdsinc/permits1.htm.)

\section{Replacement and Repair Costs}

Generally, the life of the BIPV power system is specified to last 25 years, and it is presumed that none of the BIPV power system subparts will require major replacement or repair during the study time frame, which is also often set equal to 25 years. (Minor repairs and small replacements needed to keep the system operational can be included in maintenance costs.) Of course, this is simply a modeling convention. In some instances, a part (likely, the inverter) may require major replacement or repair prior to 25 years and if preferred, these costs can be included separately in the BLCC model.

\section{Salvage Value/Costs}

As another modeling convention, it is usually assumed at the end of the study period that there is no residual value remaining for the BIPV system and no disposal costs. Again, however, this convention may not best fit the particular circumstances, and residual value and disposal costs can be explicitly estimated and included in the analysis. For example, an exception might arise if the BIPV power system is composed of hazardous materials (associated with some thin-film PV technologies), which would require removal and generate significant disposal costs. Also, if batteries must be disposed, there may be a salvage value or disposal cost depending on possible reuse value or cost of disposal. 


\section{Section 4 - Measurement and Verification for Building-Integrated Photovoltaics}

\section{Introduction}

This section specifies measurement and verification (M\&V) for BIPV power systems. Prescribing an internationally accepted guideline for $M \& V$ can help to ensure that generation and savings requirements in BIPV power systems will be consistently and accurately achieved.

\section{Protocol Background}

The International Performance Measurement \& Verification Protocol (IPMVP) was created in 1997 to increase reliability and savings, cut investment costs, and provide standardization required to secure lower-cost financing in energy and water efficiency projects. The Renewables Subcommittee, composed of leading experts from around the world that share a goal of strengthening and fostering the rapid growth of renewable energy technologies, have laid the groundwork for extending the success of the IPMVP to include renewable energy technologies. The Renewables Chapter provides an industry-consensus framework to measure project benefits that are important to realizing the promise of renewable energy.

\section{Objectives}

$\mathrm{M} \& \mathrm{~V}$ may have several objectives from the earliest stage of renewable energy project development through the operation of the completed system.

- $\quad \mathrm{M} \& \mathrm{~V}$ can provide load profiles and information needed to establish project feasibility.

- $\quad \mathrm{M} \& \mathrm{~V}$ can serve as a commissioning tool to confirm that systems were installed and are operating as intended.

- $\quad \mathrm{M} \& \mathrm{~V}$ results may serve as the basis for payments to a financier over the term of a performance contract - an alternative financing mechanism in which an energy service company guarantees that after energy measures are installed at a facility, energy cost will be reduced. In many respects, the success of a performance contract project hinges on verifying that the energy cost savings closely match those that were guaranteed in the solicitation.

- Data gathered from an M\&V protocol can provide ongoing diagnostics and help sustain system performance and benefits over time.

- During financing contract development, a defined, accepted, and proven M\&V protocol helps increase customer comfort and reduce transaction costs by facilitating negotiations.

- Finally, an M\&V protocol is helpful to secure the full financial benefits of emissions reductions, such as emissions trading. In order to establish compliance with Emissions Reduction Targets, a regulating body will need to adopt a protocol for measuring emissions reductions. 
$\mathrm{M} \& \mathrm{~V}$ should be scaled to the value of the project. The value of the information provided by a project's M\&V procedures should be proportional to the value of the project. The objective is to minimize the combined total cost of the M\&V program plus the cost of uncertainty in the savings. The cost of uncertainty would most often be a higher interest rate. In general, the allowable relative error in an M\&V program will be negotiated between parties, with all parties trying to minimize total cost. As a rule of thumb, M\&V costs should fall within 3\%-10\% of typical project cost savings.

\section{Options}

An M\&V program should be designed to measure and verify the specific performance claims of the deal or what the supplier is claiming to deliver. The M\&V options may be classified into four general categories. They can be used individually or in combination, as complexity of performance and cost factors dictate. These options are not necessarily listed in increasing order of complexity or cost. For example, inspection can be more or less costly than metering, depending on the application. The options follow.

Option A: Measured Capacity, Stipulated Performance-engineering estimates based on system specifications are used to stipulate savings, and the system is initially inspected to ensure that equipment was installed according to those specifications. The system is then periodically inspected to ensure the system is operating properly.

Option B: Measured Production/Consumption-long-term measurement of energy delivery over the term of a performance contract by directly metering building output, or indirectly by determining savings based on analysis of end-use electric or gas meters.

Option C: Utility Bill Analysis - inferring savings by the statistical analysis of wholefacility energy consumption without end-use metering of the system.

Option D: Calibrated Models-predicting the long-term performance of a system by calibrating (renormalizing) a computer model based on data from a short-term test. 


\section{M\&V Example: Thoreau Center for Sustainability (Option D, Calibrated Models)}

The BIPV power system at the Presidio in San Francisco, California, illustrates one M\&V approach. "The Greening of the Presidio" demonstrates the impact of successful partnerships between the private and public sector.

The Thoreau Center for Sustainability is a historic building located in the National Historic Landmark District of the Presidio. The BIPV power system is an extremely visible sustainablebuilding feature. The demonstration of this power system by the Federal Energy Management Program (FEMP), NREL, and numerous private sector partners is meant to illustrate how BIPV is a technically and economically valuable architectural element for designers.

The entry area of the Thoreau Center is a rectangular space with a roof that slopes slightly to the east and west. The roof is constructed entirely of overhead glazing, similar to a large skylight. PV cells are laminated into the 200 square feet of available overhead glazing to produce approximately $1.25 \mathrm{~kW}$ of electricity under standard operating conditions. The direct current produced by the array is converted to high-quality alternating current by a powerconditioning unit (inverter). After being converted, it enters the building to be consumed by the building electrical loads (Walker et al. 1997).

The abstract from Azerbegi and Barker's paper, Technique for Monitoring and Predicting Annual Performance of a Building Integrated Photovoltaic System, is included below.

"The U.S. Department of Energy's Federal Energy Management Program evaluated the energy and daylighting performance of a 1250-watt BIPV power system at the Thoreau Center for Sustainability located at the Presidio of San Francisco, California. System performance parameters (dc output, ac power output, interior light level, and array temperature) were measured along with environmental conditions (ambient temperature, wind speed and direction, relative humidity, solar insolation). A computer model of the system was then renormalized to provide the best match with the measured performance. To estimate energy delivery, the calibrated model was fed TMY [typical meteorological year] weather data, which takes into account array orientation, shading and reflection off the building, and the actual in-situ performance characteristics of the array and inverter.

This paper describes the instrumentation and data acquisition system, development of the form of the performance models, and the procedure used to renormalize the model coefficients. These results can be compared to other results generated using the same methodology, rather than just reporting the performance of the system over a certain monitoring period." 


\section{Importance of Measurement and Verification}

Actual M\&V results of existing projects based on the IPMVP can prove successful and provide developers, investors, lenders, and consumers with more confidence in the value of future projects. It is the intention of the IPMVP Renewables Subcommittee that the new chapter of the IPMVP provides the renewable energy community with a valuable tool for the implementation of more renewable energy projects. As innovative renewable energy financing increases worldwide, so will the need for the IPMVP and its internationally standardized framework.

\section{To Obtain the IPMVP}

The IPMVP is available in a variety of formats. To receive the document, call the Efficiency and Renewable Energy Clearinghouse (EREC) at (800) DOE-EREC, send a fax to (703) 893-0400, or an e-mail request to doe.erec@nciinc.com. Include your name, address, telephone number, and request for the IPMVP. This document is also available on the World Wide Web at http://www.ipmvp.org/. 


\section{References}

Byrne, J.; Letendre, S.; Wang, Y.D.; Nigro, R.; Ferguson, W. (1997). "Building Load Analysis of Dispatchable Peak-Shaving Photovoltaic Systems: A Regional Analysis of Technical and Economic Potential." Proceedings of the American Solar Energy Society

Conference, April. NREL/CP-520-23314. Boulder, CO: American Solar Energy Society.

Coles, L.; Packey, D.; Rau, N., Wang, Y.H. (1995). Analysis of PV Benefit Case Studies: Results and Methods. Draft. Golden, CO: National Renewable Energy Laboratory.

Currin Corporation. (September 1995). Title I, Phase I: Survey and Research, Addition of a Photovoltaic Energy Source to the Windigo Ranger Station Power System, Isle Royale National Park, Midland, MI. Midland, MI: Currin Corporation.

. (September 1995). Title I, Phase I: Survey and Research, Addition of a Photovoltaic Energy Source for South Manitou Island, Sleeping Bear Dunes, Midland, MI. Midland, MI: Currin Corporation.

Duncan, T. (4 March 1997). Meeting minutes. BLM Utah State Office, Denver, CO.

Eiffert, P. (September 1998). The Borrower's Guide to Financing Solar Energy Systems. NREL/BK-710-25104. Golden, CO: National Renewable Energy Laboratory.

Freedman, M. et al. (18 April 1995). Renewable Energy Sourcebook: A Primer for Action. Washington, DC: Public Citizen.

Green, H.J. Wan, Y. (1998). "Current Experience with Net Metering Programs."

Proceedings of Windpower '98 27 April-1 May, 1998. Washington, DC: American Wind Energy Association.

International Energy Agency (May 1996). "Photovoltaic Power Systems in the Built Environment." Prepared for ENEL.

Kalin, T.J. (1994). "PV as (a) New Architectural Element." Proceedings of the $12^{\text {th }}$ European Photovoltaic Solar Energy Conference, 11-15 April. Bedford, United Kingdom: H.S. Stephens and Associates; pp. 1847-1853.

Kiss, G.; Kinkead, J. (1993). "Building-Integrated Photovoltaics.” Proceedings of the $3^{\text {rd }}$ European Conference on Architecture 17-21 May 1993. Felmersham, United Kingdom: H.S. Stephens and Associates; pp. 288-291.

Lepley, T.; Nath, P. (1997). "Photovoltaic Covered-Parking Systems Using Lightweight, Thin-Film PV." Prepared for the $26^{\text {th }}$ Photovoltaic Specialists Conference, 30 September-3 October 1997. Piscataway, NJ: Institute of Electrical and Electronics Engineers; pp. 1305-1308. 
National Institute of Standards and Technology. (1995). LCC Program Version 4.21, Users Guide and Reference Manual. Gaithersburg, MD: National Institute of Standards and Technology.

- (October 1995). Energy Price Indices and Discount Factors for Life-Cycle Cost Analysis 1996. NISTIR 85-3273-10. Gaithersburg, MD: National Institute of Standards and Technology.

Renewable Energy Working Group. (1996). BLCC Preliminary Costing Guidelines for Renewable and Conventional Technologies. Draft. Washington, DC: Federal Energy Management Program.

Ruegg, R.T.; Marshall, H.E. (1990). Building Economics: Theory and Practice. New York: Van Nostrand Reinhold.

Starrs, T. (1994). "Net Metering of Customer-Owned, Utility-Integrated Rooftop Photovoltaic Systems." Proceedings of the 1994 Annual Conference of the American Solar Energy Society, 27-30 June. Boulder, CO: American Solar Energy Society; pp. $459-465$.

. (19 March 1999). "Plugging into the Grid: Interconnection of Net Metered Systems." Electric Revolution: New Electrical Technologies and What They Mean to You. Presentation. Portland, OR.

Starrs, T.; Wenger, H. (May/June 1998). "Net Metering and Small-Scale Renewables." Solar Today (12:3); pp. 32-35.

Swezey, B.; Sinclair, K. (December 1992). Status Report on Renewable Energy in the States. TP-462-5175. Golden, CO: National Renewable Energy Laboratory.

Urban Consortium Energy Task Force. (December 1995). PV Purchasing Guidebook for Local and State Government. Washington, DC: Public Technologies, Inc.; p. 4.

Walker, H.A.; Eiffert Taylor, P.; Hayter, S.J.; Maytum, M.; Christensen, J.; Coonen, S.; Rever, W.B. III; Vanderhoff, S. (1997.) Building Integrated Photovoltaic System: The Thoreau Center For Sustainability. Boulder, CO: American Solar Energy Society.

Wan, Y. (December 1996). Net Metering Programs. SP-460-21651. Golden, CO: National Renewable Energy Laboratory.

West, R.E.; Kerith, F. (1988). Economic Analysis of Solar Thermal Energy Systems. Cambridge, MA: Massachusetts Institute of Technology Press; 435 pp.

Wohlgemuth, J. (10 May 1996). Interview with author. Solarex, Frederick, Maryland. 
. (1997). Cast Polycrystalline Silicon Photovoltaic Module Manufacturing

Technology Improvements. Semiannual Technical Report. NREL/SR-520-22503.

Golden, CO: National Renewable Energy Laboratory. 


\section{Appendix}

\section{Methods of Assessing Capital Budget Decisions}




\begin{tabular}{|c|c|c|c|c|}
\hline Method of Analysis & $\begin{array}{c}\text { General Formulas } \\
\text { (All dollar amounts expressed } \\
\text { at present value) }\end{array}$ & Selection Criteria & Benefits & Disadvantages \\
\hline $\begin{array}{l}\text { Discounted Payback Period } \\
\text { (DPB) } \\
\text { Minimum time it takes to } \\
\text { recover an investment. }\end{array}$ & $\begin{array}{l}\text { DPB }=\text { Find } \mathbf{Y}, \\
\text { such that } \mathbf{Y} \sum\left(\mathbf{E}_{\mathbf{J}}-\mathbf{M}_{\mathbf{J}}-\mathbf{R}_{\mathbf{J}}+\mathbf{S}_{\mathbf{J}}\right)=\mathbf{P} \\
\boldsymbol{j}=\mathbf{1} \\
\mathrm{Y}=\text { summation from years } 1 \text { to } \mathrm{Y} \\
\mathrm{E}=\text { reduction in electricity costs in year } j \\
\mathrm{M}=\text { differential maintenance and repair } \\
\quad \text { costs in year } j \\
\mathrm{R}=\text { differential replacement costs } \\
\quad \text { in year } j \\
\mathrm{~S}=\text { differential salvage value in year } j \\
\mathrm{P}=\text { differential purchase and } \\
\quad \text { installation costs } \\
\end{array}$ & $\begin{array}{l}\text { Payback period is } \\
\text { less than the project } \\
\text { life. }\end{array}$ & $\begin{array}{l}\text { a) Simple payback is a quick } \\
\text { screening tool } \\
\text { b) Useful when system life is } \\
\text { uncertain. }\end{array}$ & $\begin{array}{l}\text { a) Only indicates when the } \\
\text { system is paid for. This } \\
\text { does not provide } \\
\text { long-term evaluation of } \\
\text { energy performance } \\
\text { b) If simple payback, only } \\
\text { accounts for investment } \\
\text { costs, not } \\
\text { comprehensive } \\
\text { c) Investments with longer } \\
\text { payback periods may } \\
\text { yield greater returns. }\end{array}$ \\
\hline $\begin{array}{l}\text { Net Benefit (NB) Analysis } \\
\text { (B - C) } \\
\text { Benefits net of costs } \\
\text { expressed as an initial } \\
\text { lump-sum amount. }\end{array}$ & $\begin{array}{l}(\mathbf{B}-\mathbf{C})=\mathbf{E}-(\mathbf{P}-\mathbf{S}+\mathbf{M}+\mathbf{R}) \\
\mathrm{E}=\text { reduction in electricity costs } \\
\mathrm{P}=\text { differential purchase and installation } \\
\quad \text { costs } \\
\mathrm{S}=\text { differential salvage value } \\
\mathrm{M}=\text { differential maintenance and repair } \\
\quad \text { costs } \\
\mathrm{R}=\text { differential replacement costs }\end{array}$ & $\mathrm{NB}>0$ & $\begin{array}{l}\text { a) Useful when there are } \\
\text { multiple kinds of benefits } \\
\text { and not just cost avoidance } \\
\text { b) Provides long-term } \\
\text { evaluation of system } \\
\text { performance } \\
\text { c) Good for design and sizing } \\
\text { systems. }\end{array}$ & $\begin{array}{l}\text { Not always reliable for } \\
\text { comparing one investment } \\
\text { opportunity with other non- } \\
\text { mutually exclusive } \\
\text { opportunities. }\end{array}$ \\
\hline $\begin{array}{l}\text { Savings-to-Investment } \\
\text { Ratio (SIR) } \\
\text { Numerical ratio that } \\
\text { represents how many times } \\
\text { savings exceed costs, over } \\
\text { and above compensating for } \\
\text { the time value of money. }\end{array}$ & $\begin{array}{l}\mathbf{S I R}=\quad(\mathbf{E}-\mathbf{M}) \\
\quad(\mathbf{P}-\mathbf{S}+\mathbf{R}) \\
\mathrm{E}=\text { reduction in electricity costs } \\
\mathrm{M}=\text { differential maintenance and repair } \\
\quad \text { costs } \\
\mathrm{P}=\text { differential purchase and installation } \\
\quad \text { costs } \\
\mathrm{S}=\text { differential salvage value } \\
\mathrm{R}=\text { differential replacement costs }\end{array}$ & SIR $>1$ & $\begin{array}{l}\text { a) Can be used to determine } \\
\text { the cost effectiveness of a } \\
\text { project } \\
\text { b) Can be used to rank } \\
\text { projects when there is a } \\
\text { limited budget. }\end{array}$ & $\begin{array}{l}\text { a) Ratio may change } \\
\text { depending on which } \\
\text { amounts are placed in the } \\
\text { numerator or } \\
\text { denominator } \\
\text { b) Does not directly show } \\
\text { magnitude of net savings } \\
\text { in monetary terms. }\end{array}$ \\
\hline
\end{tabular}




\begin{tabular}{|c|c|c|c|c|}
\hline Method of Analysis & $\begin{array}{c}\text { General Formulas } \\
\text { (All dollar amounts expressed } \\
\text { at present value) }\end{array}$ & Selection Criteria & Benefits & Disadvantages \\
\hline $\begin{array}{l}\text { Adjusted Internal Rate of } \\
\text { Return (AIRR) } \\
\text { Measures annual yield from a } \\
\text { project assuming } \\
\text { reinvestment of interim } \\
\text { proceeds at the MARR. }\end{array}$ & $\begin{array}{l}\text { AIRR }=\text { Find the } n^{\text {th }} \text { root of the ratio of } \\
\text { the terminal value of all cash flows } \\
\text { (except investment costs) to the present } \\
\text { value of investment costs and } \\
\text { subtract } 1 \\
\text { AIRR }=(\mathrm{TV} / \mathrm{PVI}) 1 / n-1 \\
\text { TV }=\text { terminal value of all cash flows } \\
\quad \text { except investment costs } \\
\mathrm{PVI}=\text { present value of investment costs } \\
1 / n=n^{\text {th }} \text { root of the ratio of TV/PVI }\end{array}$ & $\begin{array}{l}\text { AIRR must be equal } \\
\text { to or greater than the } \\
\text { investor's minimum } \\
\text { rate of return. }\end{array}$ & $\begin{array}{l}\text { a) Measure of cost } \\
\text { effectiveness } \\
\text { b) Ability to rank non- } \\
\text { mutually exclusive projects } \\
\text { when there is a limited } \\
\text { budget. }\end{array}$ & $\begin{array}{l}\text { Does not directly show } \\
\text { magnitude of net savings or } \\
\text { benefits in monetary terms. }\end{array}$ \\
\hline $\begin{array}{l}\text { Life-Cycle Cost (LCC) } \\
\text { Present value sum of costs } \\
\text { over life of a system. }\end{array}$ & $\begin{array}{l}\mathbf{L C C}=\mathbf{P}-\mathbf{S}+\mathbf{M}+\mathbf{R}+\mathbf{E} \\
\mathrm{P}=\text { purchase and installation costs } \\
\mathrm{S}=\text { salvage value } \\
\mathrm{M}=\text { maintenance and repair costs } \\
\mathrm{R}=\text { replacement costs } \\
\mathrm{E}=\text { electricity costs }\end{array}$ & $\begin{array}{l}\text { Compare LCC } \\
\text { among mutually } \\
\text { exclusive } \\
\text { alternatives. } \\
\text { Minimum LCC } \\
\text { LCC1 < LCC2 }\end{array}$ & $\begin{array}{l}\text { a) Cost effectiveness measure } \\
\text { b) Can be used to design or } \\
\text { size a system where costs } \\
\text { predominate } \\
\text { c) Best for cost-focused } \\
\text { decisions } \\
\text { d) Can be used for qualitative } \\
\text { trade-off analysis (e.g., } \\
\text { is increasing LCC by a } \\
\text { certain amount worth } \\
\text { gaining a certain quantity } \\
\text { of avoided emissions } \\
\text { e) Comparison of two } \\
\text { alternative LCCs yields } \\
\text { net savings of the low } \\
\text { relative to the high. } \\
\end{array}$ & $\begin{array}{l}\text { Not sufficient for ranking } \\
\text { among projects when there } \\
\text { is a budget constraint. }\end{array}$ \\
\hline
\end{tabular}

Source: NIST 1995 


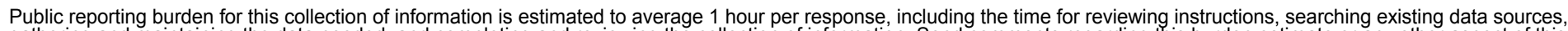

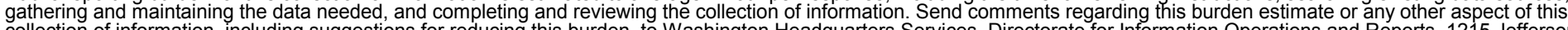

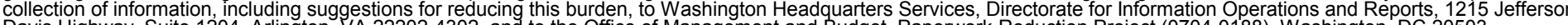
Davis Highway, Suite 1204, Arlington, VA 22202-4302, and to the Office of Management and Budget, Paperwork Reduction Project (0704-0188), Washington, DC 20503.
1. AGENCY USE ONLY (Leave blank)
2. REPORT DATE February 2000
3. REPORT TYPE AND DATES COVERED Technical Report

4. TITLE AND SUBTITLE U.S. Guidelines for the Economic Analysis of Building-Integrated Photovoltaic Power Systems

6. $\operatorname{AUTHOR}(\mathrm{S})$

P. Eiffert and A. Thompson

7. PERFORMING ORGANIZATION NAME(S) AND ADDRESS(ES) National Renewable Energy Laboratory 1617 Cole Blvd. Golden, CO 80401-3393

5. FUNDING NUMBERS

TA: FE00.6020

8. PERFORMING ORGANIZATION REPORT NUMBER

NREL/TP-710-25266

9. SPONSORING/MONITORING AGENCY NAME(S) AND ADDRESS(ES) National Renewable Energy Laboratory

10. SPONSORING/MONITORING 1617 Cole Blvd. AGENCY REPORT NUMBER

Golden, CO 80401-3393

11. SUPPLEMENTARY NOTES

12a. DISTRIBUTION/AVAILABILITY STATEMENT

National Technical Information Service

12b. DISTRIBUTION CODE

U.S. Department of Commerce

5285 Port Royal Road

Springfield, VA 22161

13. ABSTRACT (Maximum 200 words)

Traditionally, electrical service for buildings has been provided by one pre-determined supplier-the utility company. An unexpected side effect of the privatization and deregulation of the electricity industry, initiated during the late 1980s and early 1990s, is the opportunity for consumers to purchase electricity from a variety of energy service companies or to generate electricity themselves. Concurrently, the U.S. Department of Energy, national energy laboratories, universities, and photovoltaic (PV) manufacturers have technically evaluated, tested, and demonstrated building-integrated photovoltaics (BIPV) to be a viable technology.

Electricity industry restructuring and successful PV research and development raise a dilemma for building owners: is it worth the investment and effort to engage in the process of generating electricity with photovoltaics for individual buildings?

A BIPV power system operates as a multifunctional building construction material; it generates energy as well as serves as part of the building envelope. The objective of the U.S. Guidelines for the Economic Assessment of BuildingIntegrated Photovoltaic Power Systems is to identify the economic parameters of BIPV systems. Identifying these parameters will enable the decision-makers to appraise the economic feasibility and implications of investments in such building systems.

14. SUBJECT TERMS

building-integrated photovoltaic, power systems, BIPV, FEMP, Federal Energy

Management Program, National Center for Photovoltaics, NCPV, economic guidelines

15. NUMBER OF PAGES

16. PRICE CODE

17. SECURITY CLASSIFICATION OF REPORT Unclassified
18. SECURITY CLASSIFICATION OF THIS PAGE Unclassified
19. SECURITY CLASSIFICATION OF ABSTRACT Unclassified
20. LIMITATION OF ABSTRACT

UL 